\title{
Lozan Barış Konferansı ve Musul Meselesi Görüş̧melerinde Nasturilerin Durumu
}

\author{
Dr. Deniz BAYBURT ${ }^{*}$
}

\begin{abstract}
$\ddot{O}_{z e t}$
Mezopotamya'nın en eski halklarından olan Süryaniler, $\mathrm{Hz}$ İsa'nın tabiatı ile ilgili görüş̧ ayrıllkları neticesinde çeşitli gruplara bölünmüşlerdir. Bu gruplardan biri olan Nasturiler, Osmanle Devleti hakimiyeti altında inanç, ibadet ve yaşamlarına karışılmaksızın huzur içinde yaşarken Birinci Dünya Savaşı'nda Batılı devletlerin etkisiyle Osmanlı Devleti'ne karşı ayaklanmışlardır. Nasturiler, Millli Mücadele döneminde de olumsuz faaliyetlerde bulunmuşlardır.
\end{abstract}

Bu makalede Lozan Barış Antlaşması'nın imzalanması ve bunu takip eden günlerde özellikle Musul meselesi görüşmelerinde Nasturilerin durumu anlatılmaya çalışılmuştır.

Anahtar Kelimeler: Süryaniler, Nasturiler, Lozan Barış Antlaşması, Musul Meselesi

\section{Nestorians' Situation on Lausanne Peace Treaty and the Negotiations for Mosul Affair}

\begin{abstract}
The Assyrians that is one of the oldest people of the Mesopotamia has been divided into various groups because of the difference of opinion about the nature of Jesus. While the Nestorians that is one of these groups were living in peace without interfering their beliefs, religious ceremonies, and life styles by Ottoman Empire under its sovereignty, they revolted against Ottoman Empire under the influence of western states during the World War I. They also involved in hostile acts during the national struggle.
\end{abstract}

* İhtiyaç Akademi Tarih Editörü, e-posta: deniz_b01@hotmail.com 
Signing of Lausanne Peace Treaty and Nestorians' situation in the period that followed the negotiations for Mosul Affair are tried to be expreesed in this article.

Key Words: Assyrians, Nestorians, Lausanne Peace Treaty, The Mosul Affair

\section{GíRIS}

Mezopotamya adı verilen Fırat ve Dicle Nehirleri arasındaki coğrafya, tarihin en eski devirlerinden beri çok sayıda din ve ırkın ortaya çıktığı bir bölge olma özelliğini taşır. Sümer, Asur, Aram, Elam, Akad, Keldani gibi kavimlerin büyük bir çoğunluğu bu bölgede yaşamlarını sürdürmüşlerdir ${ }^{1}$. İşte kökenleri eski Mezopotamya kavimlerine dayanan ve Hristiyanlı ̆̆ 1 kabul etmeden önce bilinen bir kavim olan Süryaniler ${ }^{2}$ Hristiyanlığı kabul ettikten sonra da karşımıza çıkmaktadır.

Süryanilerin başlangıçta tek bir kilise çatısı altında toplanmış olduğunu söylemek mümkündür. Antakya Süryani Kilisesi ${ }^{3}$ kurulduktan sonra Hristiyanlık gerek siyasi gerekse dini problemler yaşamıştır. Hz İsa'nın tabiatı ile ilgili görüş ayrılıkları neticesinde Hristiyan konsilleri toplanmış ve konsil kararlarına bağlı olarak da ayrılıklar meydana gelmiştir. Bu noktada

${ }^{1}$ Kadir Albayrak, Keldaniler ve Nasturiler, Ankara, Vadi Yayınları, 1997, s. 32-33.

${ }^{2}$ Süryani halkının menşei ile ilgili olarak üç farklı görüş ileri sürülmektedir. Bunlardan birincisi; Süryanilerin Arami ırkına mensup oldukları yönündeki görüstür. Buna göre Süryaniler, Hz Nuh'un Sam, Ham ve Yafes adındaki üç oğlundan Sam'ın oğlu Aram'dan türemişlerdir. Aramilerin bir kısmı Hristiyanlığı kabul ettikten sonra putperestlikte kalan Aramilerden ayırt edilmek için "Süryani” adını almışlardır. Aziz Günel, Türk Süryaniler Tarihi, Diyarbakır, Oya Matbaası, 1970, s. 30; B.Murat Öztemir, Yezidiler ve Süryaniler, İstanbul, Ekin Yayınları, 1988, s. 34. Yani başka bir ifadeyle Süryani kelimesi, Mesihi/Nasrani kelimesinin esanlamlısı olarak kullanılmaya başlanmıstır. Kadir Albayrak, "Günümüzde Türkiye'deki Keldani Kilisesi”, Dinler Tarihi Araștırmaları III, Hıristiyanlık Dünü, Bugünü ve Geleceği , Sempozyum, 9-10 Haziran 2001, Ankara, Dinler Tarihi Derneği Yayınları, 2002, s. 29. Bu görüş dini görüş olarak nitelendirilebilir. İkinci görüş; Süryanilerin $\mathrm{Hz}$ İsa'dan sonra Hristiyanlığ 1 kabul eden Asurlular olduğu yönündedir. Bu görüşün savunucularına göre; aynı coğrafyada yaşayan halklar Hristiyanlık çatısı altında kaynaşmıșlar ve Süryani adında bir ulus meydana getirmişlerdir. İbrahim Özcoşar, Bir Yüzyıl Bir Sancak Bir Cemaat,19. Yüzyılda Mardin Süryanileri, İstanbul, Beyan Yayınları, 2008, s. 25. Bu görüsüun temelinde Süryanilerden siyasi bir toplum yaratma çabası yatmaktadır. Üçüncü görüş ise; Süryanilerin İsa'dan önceki Mezopotamya halklarının devamı olduklarını savunan görüştür. Bu görüş; onları tek bir halka bağlamak yerine, tüm Mezopotamya halklarının kültürel temeline dayanan ve Helenistik uygarlığı da özümseyerek ortaya çıkmış bir sentez olarak niteler. Bu görüş ilk iki görüşün eksikliklerini gidermek adına ortaya çıkmış sentezci bir görüștür. Nihat Durak, "Süryani Ortodoks Kilisesi”, Süryaniler ve Süryanilik, Haz. Ahmet Taşğın, Eyyüp Tanrıverdi, Canan Seyfeli, C. I, Ankara, Orient Yayınları, 2005, s. 190. Yaygın olarak kabul edilen bu üç görüsşten başka bazı yazarlar, Aramilerin Sami değil Turani olduklarını, dolayısıyla Süryanilerin ırk ve menșe olarak Türk olduklarını savunmaktadırlar. Ayrıntılı bilgi için Bkz. Mithat Sertoğlu, Süryani Türklerinin Siyasi ve İçtimai Tarihi, İstanbul, Baha Matbaası, 1974, s. 84; Mehlika Aktok Kaşgarlı, Mardin Yöresi Halkından Türko-Semitler, Kayseri, Erciyes Üniversitesi Yayınları, 1991, s. 7-8.

${ }^{3}$ Antakya Süryani Kilisesi'nin kuruluşu ve gelişimi ile ilgili ayrıntılı bilgi için Bkz. Mehmet Çelik, Süryani Tarihi (I), Ankara, Ayraç Yayınevi, 1996. 
diyebiliriz ki, Süryaniler denince etnik kökenden çok Süryani geleneğinden gelen bütün kiliseler ve onların mensupları anlaşılmaktadır. Süryani geleneğinden gelen kiliseler ise şunlardır: Süryani Ortodoks Kilisesi (Süryani Kadimler veya Yakubiler), Süryani Nasturi Kilisesi, Maruni Kilisesi, Keldani Kilisesi, Süryani Katolik Kilisesi, Süryani Melkit Kilisesi. Daha sonra bunlara Süryani Protestan Kilisesi de katılmıştır ${ }^{4}$.

Süryaniler yaşadıkları coğrafyaya hâkim olan Bizans İmparatorluğu ve Sasanilerden dönem dönem çok büyük baskı ve zulüm görmüşlerdir. Süryaniler, Bizans İmparatorluğu'nun dini görüşünden farklı bir Hristiyanlık inancına sahip olduklarından heretik sayılarak katliamlara uğramışlardır. İslam fetihleriyle birlikte yaşadıkları toprakların Müslümanların eline geçmesiyle Süryaniler ve Nasturiler daha rahat bir hayata kavuşmuşlardır. Türklerin Anadolu topraklarına ilk gelişlerinde de burada yaşayan Süryanilerle ilişkileri oldukça olumlu seyretmiştir. Kimsenin dinine ve inancına karışmayan Türklerin fetihleri Süryaniler arasında sevinçle karşılanmıştır diyebiliriz ${ }^{5}$.

Selçuklular ve Anadolu Beylikleri dönemlerinde İslam Hukuku'na göre yönetilen Süryanilerin Osmanlı Devleti dönemindeki statüleri de değişmemiştir.

Kudüs'ün Yavuz Sultan Selim'in fethi ile Osmanlı topraklarına katılması sonucu bölgede yaşayan Süryaniler de Osmanlı idaresi altına girmişlerdir. Osmanlı Devleti'nin uygulamış olduğu millet sistemi içerisinde yerlerini alan Süryaniler ve Süryani geleneğine bağlı diğer kilise mensupları tıpkı Ermeniler, Rumlar ve Yahudiler gibi refah içerisinde yaşamışlardır. İslam'ın zimmet hukukuna dayanan yönetim anlayışı sayesinde ayin ve ibadetlerini özgürce icra etme, kendi dini liderlerini seçme, kiliselerini faal tutabilme yani özetle dini konularda tamamen özgür olma imtiyazlarını ellerinde bulunduran Süryaniler, İslamlaştırma politikasıyla karşı karşıya kalmamışlar, tıpkı diğer cemaatler gibi baskıya maruz kalmadan hayatlarını devam ettirmişlerdir.

Osmanlı Devleti'nin giderek zayıflaması Batılı devletlerin Osmanlı topraklarını paylaşma isteklerini yoğunlaştırmıştır. 19. yüzyılın sonlarından itibaren doğunun zengin ham madde kaynakları Batılı devletlerin

${ }^{4}$ Burada bir kavram karmaşası karşımıza çıkmaktadır. Örneğin, Süryani denildiğinde bazen Keldani, bazen Nasturi ya da bunun tam tersi olarak Keldani ya da Nasturi denildiğinde diğerleri kastedilmekte ya da anlaşılmaktadır. Bu durumdan araştırmacılardan öte bu gruplara mensup kişiler de şikâyetçidirler. Sonuçta tüm bu gruplar aynı ırk ve aynı dinden olmalarına rağmen farklı mezheplere bölünmüşler ve bu da Hz İsa ve Meryem'e bakış açılarından kaynaklanmıştır. Ancak bu durum liturjik uygulamalarda çok da fazla farklılıklara sebep olmamaktadır. Albayrak, a.g.e., s. 70-71.

${ }^{5}$ Osman Turan, Türk Cihan Hakimiyeti Mefkuresi Tarihi, C.I, İstanbul, Turan Neşriyat, 1969, s. 203-204. 
emperyalist emellerini su yüzüne çıkarmıştır. Başta petrol olmak üzere zengin ham madde kaynaklarına sahip toprakların sömürgeleştirilmesi arzusu Osmanlı topraklarında Batılı devletlerin birbirleriyle olan yarışını da beraberinde getirmiştir. Batılı devletlerin emperyalist politikalarını gerçekleştirilebilmek için Osmanlı Devleti topraklarında yaşayan gayr-i Müslimleri kullandıklarını söylemek yanlış olmaz. Bunu yaparken kullandıkları en önemli kaynak da şüphesiz misyonerler olmuştur. Batılı devletler, gönderdikleri misyonerler vasıtasıyla gayr-i Müslim topluluklar içerisinde bir ulus bilinci yaratmaya çalışmışlar bunda da başarılı olmuşlardır. Misyonerler dini konularda oldukça cahil buldukları cemaatleri eğitmek maksadıyla hareket ediyormuş gibi görünerek onlar arasında ayaklanma fikirleri oluşturmaya çalışmışlardır. Bu çalışmalardan Süryaniler de etkilenmişlerdir. Katolik misyonerlerin faaliyetleri sonucu pek çok Süryani Katolik olurken Protestan misyonerlerinin faaliyetleri de Protestan Süryani grubunun oluşması ile sonuçlanmıştır.

Osmanlı Devleti Birinci Dünya Savaşı'na girince devlet bünyesindeki Hristiyan azınlıklar, emperyalist devletlerin vaatlerine inanarak Osmanlı Devleti aleyhine ayaklanmış ve savaşmışlardır. Bu bağlamda bağlı bulundukları devlete karşı ayaklanan Nasturiler de savaş sonunda emperyalist devletlerin vaatlerinin tutulmaması ile hayal kırıklığına uğramışlardır. Savaşın ilk yıllarında Rusya'nın koruyuculuğunda Osmanlı Devleti'ne karşı hareket eden Nasturiler, 1917 İhtilali'nden sonra bu defa İngiltere'nin yanında yer almışlardır.

Birinci Dünya Savaşı sonrası Irak'ta İngiltere idaresinde kurulan Bakuba Kampı'na yerleştirilen Nasturilerin sorunları bitmemiştir. Onların sürekli olarak yerleşebilecekleri bir bölgenin bulunması gerekmekteydi. Nasturilere bir yer bulma çabaları sırasında onlardan Türk etki sahası ile İngiliz denetimi altındaki Mezopotamya arasında bir tampon bölge oluşturulması düşüncesi ortaya çıkmıştır .

İngilizler silahlandırdıkları Ermeni ve Nasturileri her firsatta kullanmışlardır ${ }^{7}$. Nasturilerin İngilizlerin yardımıyla yaptıkları bu faaliyetler bir tarafa bırakılacak olursa açıkça ifade etmek gerekir ki Yakubiler olarak da bilinen Süryani Kadimler birkaç küçük hadise dışında bu faaliyetlere karışmamışlardır. Süryani Kadimler her zaman itaatkâr bir cemaat olmuş asla devlet kurma sevdasına kapılmamışlardır. Sadece yaşadıkları toprakların vatandaşları ile aynı haklara sahip olmak istemişlerdir ${ }^{8}$.

${ }^{6}$ Yonca Anzerlioğlu, “XIX. Yy. ve Sonrasında Nasturi Hıristiyanlarının Faaliyetleri”, Türk Yurdu, C. XVIII, S. 134, Ekim 1998, s. 180.

$7 \mathrm{Bu}$ faaliyetlerle ilgili ayrıntılı bilgi için Bkz. Deniz Bayburt, Türk Tarihi'nde Süryaniler(1880-1938), Basılmamıș Doktora Tezi, Gazi Üniversitesi Sosyal Bilimler Enstitüsü, Ankara, 2009, s. 172-175.

${ }^{8}$ Aksiyon, 2-8 Mart 2002, s. 23. 
Birinci Dünya Savaşı'ndan sonra Hakkari ve çevresine geri dönmek ve İngiltere denetiminde özerk bir devlet kurmak amacinda olan Nasturiler bu hedeflerinin siyasi platforma taşımaya ve bu amaçla Paris ve San Remo Konferanslarında seslerini duyurmaya çalışmışlardır. Durumlarının sadece büyük devletlerin çıkarlarına göre belirlenebileceğini anlayamayan Nasturiler, bağımsız bir devlet kurabilmek için konferanslardan istedikleri sonuçları alamayınca San Remo Konferansı'nı takiben yeni bir harekâta girişmişlerdir.

Bu harekât planına göre Türk-İran sınırındaki bir bölge işgal edilecek, Hakkari ile Urmiye birleşecek ve Türkiye-İran-Irak arasında bir tampon devlet kurulacaktı. Ancak bu plan da başarısızlıkla sonuçlanmıştır.

$\mathrm{Bu}$ arada kapatılan Bakuba Kampı'nın yerine Akra yakınlarında Mindan Kampı kurulmuştu. Hakkari harekâtından dönmeyi başarabilen ve Bakuba'dan ayrılan 20.000 kadar Nasturi bu kampa yerleşmişlerdir.

İngilizler Nasturilerin gizlice Türk hududundan sızarak eski yerlerine yerleşmelerini planlamışlardır. Mindan Kampı sakinleri ülkelerine dönmeye zorlandılar. Bunlardan genellikle çiftçilikle geçinen Urmiye kökenli Nasturilerin büyük bölümü ağır koşullara dayanamayarak ya da Kürtlerin saldırıları sonucu hayatını kaybetmiş geride kalanlar ise Bağdat ve Musul'a kaçarak sefalet içinde yaşamlarını devam ettirmeye çalışmışlardır. Hakkarili Nasturiler ise daha sağlam yapılı ve savaşçı olduklarından zor şartlara dayanabilmişlerdir. Yaklaşık $7500^{9}-8000$ Nasturi ${ }^{10}$ Musul Ovası ile Dohuk, İmadiye ve Zaho'daki dağların yamaçlarındaki boş köylere ya da Hakkari'ye gelerek yerleşmişlerdir. 6500 kadar Nasturi ise Nasturi komutan Ağa Petros ile birlikte hareket etmeyi tercih ettikleri için kendi hallerine bırakılmışlar bir kısmı Suriye'ye gelmişler bir kısmı da değişik yerlere dağılmışlardır. Hakkari'ye gidenlerin bir bölümü daha sonra geri dönmüşler ama çoğu 1924 Nasturi ayaklanmasına kadar orada yaşamışlardır ${ }^{11}$.

$\mathrm{Bu}$ bilgilerden de anlaşılacağı gibi İngiltere, Birinci Dünya Savaşı sırasında çeşitli vaatler verdiği ve Osmanlı Devleti'ne karşı kışkırttığı Nasturilere, savaşın sonunda sahip çıkmamıştır. Bununla birlikte İngiltere, yeni politikalarında tekrar kullanmak üzere Nasturiler üzerinde hesaplar yapmaktan ve yeni vaatlerde bulunmaktan geri durmamıştır. 1914-1945 yılları arasında İngiliz hükümeti tarafından İran ve Irak'ta görevlendirilen Ortodoks bir din adamı olan William Wigram'ın İngiliz politikası hakkında söylemiş olduğu şu sözler bu gerçeği teyit etmektedir: "Bizler (Ingilizler)

${ }^{9}$ İhsan Şerif Kaymaz, Musul Sorunu Petrol ve Kürt Sorunlart ile Bağlantılı Tarihsel ve Siyasal Bir Inceleme, Ístanbul, Otopsi Yayınlar1, 2003, s. 180-181.

${ }^{10}$ Faik Bulut, Kürdistan'da Etnik Çatışmalar Dar Üçgende Üç Isyan, 2. Baskı, İstanbul, Evrensel Basım Yayın, 2005, s. 201.

${ }^{11}$ Kaymaz, a.g.e.,s. 181-182. 
Süryanileri resmen kullandık. Onları düpedüz aldattı. Vaatlerimize kandıklarından her verdiğimiz işi yaptılar. Ama daha sonra onları düşmanın eline terk ettik ki öclerini alabilsinler. Bu konu Cemiyet-i Akvam'da ele alındı. Alınan karar gereğince güya Süryanilere bir yurt verilecekti. Özellikle bizler onların acı çekmelerine neden olduğumuzdan parayla bile olsa böyle bir yurt bulmalıydık."12

Sonuç olarak diyebiliriz ki 1918-1922 yılları arasında İngiltere'ye sığınan yaklaşık 35.000 Nasturi'nin bir kısmı zor şartlar altında çeşitli yerlere yerleştirilmiş geriye kalanlar ya ölmüş ya da dağılmışlardı. İngiltere ise zulme uğrayan bu halkın korunduğu propagandasını sonuna kadar kullanacak, siyasi amaçları uğruna her fırsatı değerlendirdikleri gibi bunu da değerlendireceklerdi. Güç ve propagandaya sahip olan İngiltere, cahil ve çaresiz Nasturileri paralı askerler olarak kullanmaya devam etmiştir ${ }^{13}$.

\section{Lozan Barış Konferansı'nda Nasturiler}

Paris ve San Remo Konferansları'nda yapılan uzun müzakereler sonrasında Osmanlı Devleti Sevr Antlaşması'nı imzalamıştır. Ancak mütarekenin imzalanmasından hemen sonra memleketin her yöresinde kurulan milli mukavemet teşkilatları ile Mustafa Kemal'in de önderliğinde milli mücadele başlamıştır. Toplanan kongreler ve alınan kararlarla, "Milletin istiklalini yine milletin azim ve kararı kurtaracaktır" ilkesine dayanarak Sevr kararları reddedilmiştir. İşgalci devletlerle yapılan mücadeleler ve art arda kazanılan zaferler sonucunda Mudanya Mütarekesi imzalanmış barış görüşmeleri süreci hızlanmıştır. Müttefik Devletler Lozan'da bir konferansın toplanması kararını almışlardır ${ }^{14}$.

20 Kasım 1922'de başlayan konferansın gündemini meşgul eden en önemli konular Boğazlar, sınırlar, Osmanlı borçları, Musul meselesi olmakla birlikte bu çalışmada Lozan Konferansı'na detaylı bir şekilde girilmeden azınlıklarla ilgili müzakerelerin Nasturilerle ilgili kısımları ele alınacaktır.

Azınlıklar meselesi Lozan Konferansı'nın iç tüzüğünün 5. Maddesine göre kurulan Yabancılar ve Azınlıklar Komisyonu'nda görüşülecekti. Ancak mesele Lord Curzon tarafından ele alınınca konu ilk defa 12 Aralık 1922'de gündeme getirilmiştir ${ }^{15}$.

Süryaniler ise ilk defa Ermeni yurdu meselesi tartış1lırken gündeme gelmişlerdir. Lord Curzon, Nasturilerle ilgili olarak da; Kürdistan dağlarının muhtelif yerlerinde ve Türk-İran hududu üzerinde yaşayan Nasturilerin savaş

\footnotetext{
${ }^{12}$ Bulut, a.g.e., s. 199.

${ }^{13}$ Kaymaz, a.g.e., s. 182.

${ }^{14}$ Veysi Akın, "Lozan Barıs Antlaşması (24 Temmuz 1923)", Türkler, C. XVI, Ankara, Yeni Türkiye Yayınları, 2002, s. 306-308.

${ }^{15}$ Hikmet Öksüz, "Lozan'da Azınlıklar Meselesi”, Türk Yurdu, Kasım 1987, s. 88.
} 
zamanında çok ıstırap çektiğini ve bunların mukadderatıyla İngiltere, Fransa ve Amerika'nın alakadar olduğunu, şu anda İngiltere nüfuzuna tabi mıntıkalarda bulunan bu cemaatin İngiltere'nin dostane himayesinden emin olduklarını ve Türk topraklarında kalan Nasturilerin din, faaliyet ve hayatlarının muhafazasını ısrarla istemeye mecbur olduklarını söylemiştir ${ }^{16}$.

İsmet Paşa ise özetle; Türkiye azınlıklarının mukadderatının ıslahının her şeyden evvel her türlü ecnebi müdahalesinin ve dışarıdan gelen tahriklerin giderilmesine bağlı olduğunu belirtmiş ${ }^{17}$ ve azınlıkların, ayrı bir toprak elde edebilmek için Türkiye'nin parçalanması ile sonuçlanacak iddialarda bulunmasını kesinlikle reddetmiştir ${ }^{18}$.

Ancak İngiltere bununla tatmin olmayıp iddialarında 1srar edince meselenin çözümü, 13 Aralık 1922 tarihli toplantıda alt komisyona havale edilmiştir. Alt komisyonu başlangıçta en çok uğraştıran konu, azınlıklar kavramının tanımlanması olmuştur. Türk heyetinin "gayr-i Müslim azınlıklar" kavramında ısrarcı olması üzerine özellikle İngiliz heyeti bazı Müslüman grupları da azınlık statüsüne sokmaya çalışmıştır ${ }^{19}$. Türk heyeti ise Türkiye'de yalnızca din azınlıklarının bulunduğunu, ırk azınlıklarının bulunmadığını ve Türk heyetinin soy ya da dil azınlıklarının korunması ilkesini kesinlikle kabul etmediğini belirtmiştir. Tartışmalar neticesinde Türk heyeti gayr-i Müslim azınlık tabirini kabul ettirmiştir ${ }^{20}$.

Bu arada Nasturi lider Ağa Petros da çalışmalarına devam ediyordu. Daha Lozan Konferansı öncesi Anadolu topraklarında otonomi isteyen taleplerini doğrudan ABD başkanına sunan Ağa Petros ${ }^{21}$, Kasım ayının başlarında Lord Curzon'a da bir mektup göndermiş ve daha önceki mektuplarındaki isteklerini tekrar etmiştir. Ağa Petros, Lozan Konferansı başladığı günlerde Londra'ya gelme talebinde bulunmuşsa da bu talep, gelmesinin bir yararının olmayacağı fikriyle reddedilmişti. Bu gelişmeye bakılırsa İngiltere, Ağa Petros'un hilekâr ve tehlikeli olduğunu düşünmektedir ${ }^{22}$.

${ }^{16}$ Yakın Doğu Meseleleriyle İlgili Lozan Barış Konferansı Tutanakları, 21 Kasım 1922 23 Temmuz 1923, Birinci Takım, C. I, 1. Kitap, Der. Ahmet Yavuz, Ankara, Dışişleri Bakanlığı Yayınları, 1968, s. 200.

${ }^{17}$ Yakın Doğu..., s. 219.

${ }^{18}$ Yaşayan Lozan, Ed. Çağrı Erhan, Ankara, Kültür ve Turizm Bakanlığı Yayınları, 2003 s. 223

${ }^{19}$ Eyüp Kaptan, Lozan Konferansında Azınlıklar Sorunu, İstanbul, Harp Akademileri Basımevi, 2002, s. 60-62.

${ }^{20}$ Görüşmelerin ayrıntıları için Bkz. Seha Meray, Lozan Barış Konferansı Tutanaklar Belgeler, Takım 1, C. I, Kitap 2, Ankara, Ankara Üniversitesi Siyasal Bilgiler Fakültesi Yayınları, 1970, s. 152-206; Yaşayan Lozan, s. 220.

${ }^{21}$ Bülent Özdemir, Süryanilerin Dünü Bugünü, I. Dünya Savaşı'nda Süryaniler, Ankara, Türk Tarih Kurumu Yayınları, 2008, s. 144.

${ }^{22}$ Salahi R. Sonyel, The Assyrians of Turkey Victims of Power Policy, Ankara, Türk Tarih Kurumu Basımevi, 2001, s. 164-165. 
Alt komisyona havale edilen azınlıklar meselesi burada da çözümlenememiştir. Türk heyeti dışarıda olan Nasturilerin tekrar Türkiye'ye dönmeleri teklifini kabul etmiyordu. 6 Ocak 1923 tarihli oturumda Montagna, Ermeni sorunu ile ilgili bir konuşma yaptıktan sonra sözü Süryanilere getirmiş ve onlarla ilgili olarak bu halkı özel bir bölgede toplamanın gerekli olduğunu ve onlara Türk hükümetinin koruyuculuğu altında barış içinde yaşama olanağının verilmesi gerektiğini belirtmişti ${ }^{23}$. İngiliz delege Sir Hurace Rumbold da "Savaştan önce Mardin, Diyarbakır ve Türk-İran sınırı arasında dă̆glmıs kentlerde ve kasabalarda, özellikle Çölemerik dolaylarındaki dağlarda ve bu sinırın ötesinde Iran'da yaşayan bu gözüpek küçük halk, savaş sırasında çok acılar çekmiş, ă̆ır kayıplar pahasına her yana dağılmıştır. Bunların binlercesi şimdi Kafkasya'da ve Güney Rusya'da bulunmaktadır; onlar da dışarıdan ve özellikle Yakın Doğu Yardım Komitesi'nden sağladıkları yardımlardan başka bir şeyleri olmaksızın ĕgreti bir hayat sürmektedirler. Bunlardan kimileri saylları azalmış olarak Mardin bölgesinde, kimileri İstanbul'da ya da uzaklarda, $A B D$ 'de yaşamaktadırlar; fakat Asuri-Keldanilerin büyük çoğunluğu savaştan önce Türkiye ve Iran sinırları üzerinde yaşarken şimdi Irak'ta Ingiliz mandası altında bulunmaktadırlar. Bunlardan 60.000'den çoğu Dicle'nin doğusunda Erbil dolaylarında en büyükleri El Köşk (El Kosh) ve Tal Hayf (Tal Kaif) olan bakımlı kasabalarda ve Dahuk ve Imadiye bölgelerinde yaşamaktadırlar. Ingiliz hükümeti bu mutsuz halkı her zaman yaşamaya alışmış oldukları dağlarda kendilerine bir barınak bulunduruluncaya kadar beslemek ve barındırmak için 4 milyon Ingiliz Lirası'ndan çok harcamıştır. Bu gözüpek halkın büyük çoğunluğunun Irak'ta Ingiliz mandast ve Milletler Cemiyeti'nin koruyuculuğu altında kalacaklar beklenebilir; fakat bir takımı da Irak'tan Türkiye'ye daha doğrusu Cölemerik dolaylarındaki yuvalarına dönmek isteyeceklerdir. Kimileri de İran'dan ya da Kafkasya'dan dönmek isteyeceklerdir. Türk hükümetinin onların geri dönüşlerini kolaylaştıracağını ve kendi dilleriyle okullarını yaşatabilmeleri, aile görenekleriyle kişisel göreneklerini sürdürebilmeleri, dinlerinin gereklerini yerine getirebilmeleri ve Türkiye'nin yurttaşları olarak huzur içinde yaşayabilmeleri için gerekli bütün güvenceleri vereceğini umarak Türk temsilci heyetine bütün bu insanlar adına çăgrıda bulunmaktayız." demiştir ${ }^{24}$.

Türk heyeti adına konuşan Rıza Nur ise Nasturilerin durumlarının tek müsebbibinin Batılı devletler olduğunu belirtmiş ve bu beyanatları yok farz etmiştir. Başkan Montagna, konferans nizamını bozmayıp Fransız

\footnotetext{
${ }^{23}$ Meray, a.g.e., Takım I, C. I, Kitap II, s. 275.

${ }^{24}$ Meray, a.g.e., Takım I, C. I, Kitap II, s. 277-278.
} 
delegesinin de dinlenmesi gerektiğini belirtmişse de Türk heyeti oturumdan çekilmiştir ${ }^{25}$.

Alt komisyonda bir sonuca bağlanamayan mesele tekrar üst komisyona gönderilmiştir. Üst komisyon 9 Ocak 1923 'de müzakerelere başlamıştır. Fransız delege M. Barrére, bir konuşma yaparak Nasturilerle ilgili olarak; "Son zamanlarda bu kadar felaketzede ve şayan-ı merhamet olan Ermeniler ve Asuri-Keldaniler gibi zümrelerin mukadderatını Türkiye heyeti murahhasasının nazarı dikkate aldı̆̆ını görmekle mesut olacă̆ım.” demiştir. İsmet Paşa ise buna karşılık olarak müttefiklerin öne sürdüğü görüşlerin Türkiye'yi taksim etmek mahiyetinde olduğunu ve Türk heyetinin bunları müzakere etmesinin imkânsız olduğunu söylemiştir ${ }^{26}$. Lord Curzon ise Türk heyetinin protesto ederek katılmadığı oturumda dinlenen Ermeniler, AsuriKeldaniler ve Trakya Bulgarları konusunu tekrar gündeme getirdikten sonra Nasturilerle ilgili olarak “...mevzubahis olan ikinci zümre Nasturilerdir. Miktarları azdır fakat bunlar ırki, tarihi, dini ve sstırapları dolayısıyla dünyada aynı ehemmiyete haiz olan her cemaatten ziyade alaka celbediyor. $\mathrm{Bu}$ millet her cihette dağınık bulunuyor; onu Türkiye ve İan'daki oturdukları yerlerden savaş kaçırmıştır. Asuri-Keldanilerin bir miktarı Irak sınırında az çok Ingiliz himayesi altında bulunuyor. Ingiltere'nin ona karşı gösterdiğ i alaka sadece lafzî değildir, Zira onlara yardım etmek için mütarekeden beri 4 milyon Lira'dan ziyade sarfetti. Asuri-Keldanilerin büyük bir kısmı ya Türkiye ülkesinde ya da Çölemerik havalisinde bulunuyor. Türkiye ülkesindeki vatanlarına dönmeyi arzu ediyorlar. Ingiltere hükümeti kendi nüfuzuna tabi bulunan ülkede sakin olan ve şuanda Türkiye'de bulunan veya oraya avdet etmek isteyen Asuri-Keldaniler lehine bütün gayretini sarfedecektir." diyerek onların lisanları, mektepleri, örf, adet

${ }^{25}$ Rıza Nur da hatıralarında konuyla ilgili olarak kendilerine celsenin başlamasına az zaman kala Ermeni ve Asuri-Keldani temsilcilerinin dinleneceğinin söylendiğini, bu tür celselerin resmi celse olmayıp zabta geçirilemeyeceğini ve Türk heyetinin iştirak etmeyeceğini söylemiş olmasına rağmen böyle bir gündem oluşturulmasına şaşırdığını dile getirdikten sonra bir nota yazdığını söylemiştir. Bu notada Rıza Nur: "Ben size söylemiştim bunlar dinleyemezsiniz. Dinlemek isterseniz biz gelmeyiz. Hem Ermeni, Asuri devlet değil ki. Biz devletlerle müzakereye geldik. Bu sebeple celseye gelmiyoruz." demiştir. Neticede Türk heyeti bu celseye katılmamış ancak hususi mahiyette yine de Bulgar, Ermeni ve Asuri temsilciler dinlenmis fakat konuşmaları zabıtnameye geçirilmemiştir. Daha sonraki oturumdan önce Montagna'nın kendisine gelerek İngiltere ve Fransa'nın Ermenileri kendi menfaatlerinde kullandıklarını bu yüzden de onlar için yurt istemeyi ahlaki bir mecburiyet olarak gördüklerini söylediğini ifade eden Rıza Nur eğer başkan sıfatıyla Montagna kısa bir konuşma yaparak Ermeni sorununu dile getirirse celseye iştirak edeceğini söylemiştir. Ancak 6 Ocak tarihli celsede durum böyle olmamış Montagna'nın yanı sıra Rumbold da konuşmuş ve hatta Fransız temsilci de söz istemiştir. Türk heyeti de bu şartlar altında celseyi terk etmiştir. Rıza Nur sözlerinin tamamının tutanaklara geçmediğini de belirtmektedir. Rıza NurJoseph C. Grew, Lozan Barış Konferansının Perde Arkası, Örgün Yayınevi, İstanbul 2003, s. 145-150; Riza Nur, Hayat ve Hatıratım, C. III, Altındağ, Y.y., 1968, s. 1059-1063.

${ }^{26}$ Yakın Doğu..., s. 328-329; Meray, a.g.e., Takım I, C. I, Kitap I, s. 297-298. 
ve dinleri hakkında tam teminat verileceğini ümit ettiğini de sözlerine eklemiştir ${ }^{27}$.

Bu sırada Nasturi lider Ağa Petros, Türk delegasyonu ile görüşmeye çalışmaktadır. A ğa Petros, Türk delegasyonuna Nasturi isteklerinin gerçekleştirilebilmesi için teklifte bulunmuştur. Buna göre Türkiye Hakkari'yi Nasturi yurdu olarak temin etmeliydi. Eğer bu gerçekleştirilemezse Gevar ve Çölemerik bölgeleri ile iki başka bölge -ki buralar görünüşe göre Başkale ve Şemdinan olacaktır- Nasturilere bırakılmalıydı. Ayrıca savaştan evvel Çölemerik ve Gevar bölgesinde oturan fakat göç etmek zorunda kalan ve bunlardan başka İran, Bağdat vs memleketlerde bulunan Nasturilerin Türk Devleti tarafından tahsis olunacak bir bölgede toplu halde bulunmalarına müsaade edilmesi istenmekteydi. Bu şartlar kabul edildiği takdirde Nasturi heyeti Türklerle bir davaları olmadığını ilan edecek ve bundan başka halen Musul ve havalisinde bulunan Keldani kıtaatı İngilizlerden ayrılarak Türklere katılacak ve eğer Türkiye arzu ederse Musul'daki amaçlarını elde edebilmek için Türkiye'ye yardım edeceklerdi. Ayrıca Ağa Petros mutabakat sağlanırsa kendisinin ve heyetinin Ankara'ya gitmeye hazır olduğunu da sözlerine eklemiştir ${ }^{28}$.

İngiltere bu görüşmeyi haber aldığında durumdan pek hoşlanmamıştı. 22 Ocak 1923'de Forbes Adam, Ağa Petros ile bir görüşme yaparak İsmet Paşa ile aralarında geçen görüşme hakkında bilgi almaya çalışmış, çeşitli kaynaklardan böyle bir görüşme yapıldığını öğrendiklerini ve neden Türk delegasyonu ile görüştüğünü sormuştur. Ağa Petros ise kendi halkının haklarının savunulması için İsmet Paşa ile görüşmesinin gerekli olduğunu, İsmet Paşa'dan savaştan önce oturdukları Van bölgesinde Nasturilere otonomi verilmesini istediğini söylemiş, ancak eski bölgelerine dönmeleri halinde İngilizlere karşı Türklerin yanında yer alacaklarına dair vaatte bulunduğunu reddetmiştir. Forbes Adam'ın Musul bölgesi hakkında İsmet Paşa ile konuşup konuşmadığı sorusuna karşılık Ağa Petros, konuştuklarını ve kendisinin İsmet Paşa'ya bölgede Türk bulunmayıp sadece Kürt, Arap ve Yezidi olduğunu fakat orijin olarak Nasturilerin bulunduğunu söylediğini ifade etmiştir. Ayrıca bu görüşmede Ağa Petros isteklerini içeren belgeyi de Forbes Adam'a vermiştir. Bu belgede Nasturilerin Türklerle her zaman dost oldukları ifadelerinin yanı sıra yer alan İngiltere'nin Musul'la ilgili planlarını tehlikeye sokabilecek düzenlemeler ciddi anlamda İngiltere'nin canını sıkmıştır. Ayrıca bu belgede Nasturiler Türklere karşı kullandıkları

${ }^{27}$ Yakın Doğu..., s. 335-336; Meray, a.g.e., Takım I, C. I, Kitap I, s. 304-305.

${ }^{28}$ Sonyel, a.g.e., s. 165-166; Lozan Telgraflart, Türk Diplomatik Belgelerinde Lozan Barış Konferansı, C. I, Haz. Bilal N. Şimşir, Ankara, Türk Tarih Kurumu Basımevi, 1990, s. 388-389; Kaymaz, a.g.e., s. 336-337. 
silahları teslim edeceklerini de belirtiyorlardı. Bu durum şüphesiz İngiltere'nin hiç işine gelmezdi ${ }^{29}$.

A ğa Petros ayrıca Lord Curzon ile bir görüşme yapmasına müsaade edilmesini istemiş ve Curzon'un mutabakatını almadan bir daha Türk heyeti ile görüşmeyeceğini de sözlerine eklemiştir. Ancak İsmet Paşa'nın 15 Ocak 1923'de Başbakan Hüseyin Rauf'a göndermiş olduğu telgraf, Ağa Petros'un gerçekleri söylemediğini göstermektedir. İsmet Paşa bu telgrafta, Ağa Petros'un yukarıda belirttiğimiz isteklerini hükümete ilettikten sonra göç edenler ile dış ülkelerdeki Nasturilerin geri dönmeleri için bir taahhütte bulunulamayacağı, zaten Nasturilerin diğer Türk vatandaşları gibi memlekette serbestçe yaşadıkları ve meselenin halli için Nasturi heyeti reisini Ankara'ya göndermek yolundaki fikrini beyan etmiştir ${ }^{30}$.

Hüseyin Rauf'un 18 Ocak 1923'de vermiş olduğu yanıt ise şöyledir: "Asuri ve Keldanilerin memleketimizde iskanlarl hususunu uygun bulmamakla beraber hiçbir taahhüdü kapsamamak üzere A ̆ga Petros'un Lozan'dan uzaklaştırılması bir fayda săglayacak ise Ankara'ya gönderilebilece ği ve adv geçen şahsin daha önce Urmiye konsolosluğumuzda tercümanlıkta istihdam edilmiş Türk tabiiyetinde bulunduğu arz olunur",31

26 Ocak'ta Ağa Petros, Forbes Adam ile görüşmek istemiştir. Forbes Adam Irak sınırı çizilene kadar Ağa Petros'un İsmet Paşa ile görüşmesinin bir kazanç sağlamayacağını ifade etmiştir. Onun bu konu ile ilgili kişisel görüşü meselenin Cemiyet-i Akvam tarafından çözüme ulaştırılması yolundadır. Ayrıca görüşmede başka hangi detayların geçtiğini de bilmek istemiştir. Bunun üzerine Ağa Petros kendisine şu bilgiyi vermiştir: Yıllardır Türklere sadık bir şekilde Musul vilayetinin kuzeyinde ve Başkale'de oldukça zor şartlar altında yaşayan ve zaman zaman bölgedeki Kürtlerin baskılarına maruz kalan Nasturilere Türkiye Cumhuriyeti'nin kurulması ile birlikte yaşadıkları bölgelerde kendi kendilerini yönetme imtiyazı Türk Devleti tarafından verilecektir. Onların Türklerden ayrılmak gibi bir arzuları yoktur. Gelecekte de geçmişteki gibi Türkiye'ye sadık kalacaklar, Türkler de kanunlar dâhilinde onların emin bir şekilde yaşamalarına imkân taniyacaktır ${ }^{32}$.

Türklerle Nasturiler arasında bir yakınlık kurulması İngiltere'nin Musul tezine ölümcül bir darbe vurabilirdi. Gerçi İsmet Paşa ile Rauf Bey arasındaki yazışmalar Türk tarafının Ağa Petros'u sadece Lozan Konferansı'ndan uzaklaştırmak istediklerini ve Nasturileri kendi yanlarına çekmek gibi bir planlarının olmadığını göstermektedir. Hatta Rauf Bey’in

\footnotetext{
${ }^{29}$ Sonyel, a.g.e., s. 166-168; Kaymaz, a.g.e., s. 337-338.

${ }^{30}$ Lozan Telgraflart, s. 388-389.

${ }^{31}$ Lozan Telgarflart, s. 399.

${ }^{32}$ Sonyel, a.g.e., s. 170-171.
} 
"Asuri ve Keldanilerin memleketimizde iskanlarl hususunu uygun bulmamakta..." şeklindeki sözlerinden Musul'un Türkiye'ye bırakılması halinde bile bölgedeki Nasturilerin sınır dışı edilmelerinin düşünüldüğü anlaşılmaktadır. Türkiye o günkü şartlar altında Nasturilerin önemini tam olarak anlayabilmiş değildił ${ }^{33}$. Oysa Türkiye Ağa Petros'u kendi yanına çekerek İngiltere'ye karşı aynı Nasturi kozunu kullanabilirdi.

Ağa Petros'un yapmış olduğu başvuru pek çok açıdan tarihi gerçekleri ortaya koymaktadır. Başvuru dilekçesinde sürekli olarak Nasturilerin yüz yıllardır Osmanlı yönetimi altında barış ve güvence içinde yaşadıkları ve Osmanlı Devleti'nin kendilerine imtiyazlar tanıdığı vurgulanmaktadır. Bu vurgu, savaş sonrasında ortaya atılan Osmanlı Devleti'nin Süryani geleneğinden gelen halklara baskı ve katliam yaptığı tezini çürütür niteliktedir. Ağa Petros tarafından, savaş sırasında soykırım yaptığı iddia edilen Türklerle Nasturi otonom bölgesi oluşturulması amacıyla görüşmeler yapılması dikkat çekici bir tezatlık oluşturmaktadır. Dilekçede "Türk milletine sadık kalacakları" ve "Geçmişte olduğu gibi Türklerin tolerans ve anlayışlarına güvendikleri" şeklindeki ifadeler, ortaya atılan soykırım iddialarının tamamen politik amaçlarla yapıldı ğının birer göstergesidir. Bir diğer talep ise İran topraklarında kalan Urmiye ve Salmas'daki Nasturilerin Türk Devleti'nin tebaası sayılması ve savaş sırasında yaşadıkları yerleri terk etmek zorunda kalan Nasturilerin geri dönmek istedikleri yönündedir. Bütün bunlara bakıldığında Nasturilerin Birinci Dünya Savaşı sırasında kendilerine soykırım yaptığını iddia ettiği Türkiye'ye sığınmaya çalışması soykırım iddiacılarına cevap niteliği taşımaktadır.

Ağa Petros'un Türkiye ile yapmaya çalıştığı anlaşmanın onun şahsi ihtirasından kaynaklandığını iddia edenler olacaktır. Unutulmamalıdır ki Ağa Petros ihtiras ve hırsına rağmen Nasturi birliklerinin komutanı ve patrikten sonra gelen en etkili kişi olma sıfatını taşımaktaydı. Böyle bir kişinin soykırım yapmakla suçlanan Türkiye ile anlaşmaya çalışmasını onun şahsi ihtirasına bağlamak yanlış bir değerlendirme olacaktır ${ }^{34}$.

Gerek Nasturilerin gerekse Avrupalı devletlerin ve özellikle de İngiltere'nin Nasturilere otonomi verilmesi yolundaki isteklerine rağmen Lozan'da bu anlamda bir başarı sağlanamamıştır. 24 Temmuz 1923'de imzalanan Lozan Antlaşması'nın azınlıkların korunması ile ilgili 37. ve 45. Maddelerine göre; Türkiye, doğum, milliyet, din, dil, ırk farkı gözetmeksizin Türk halkının tamamının hayat ve hürriyetlerinin himayesini taahhüt etmiştir. Genel adaba ve düzene uymak şartıyla Türkiye'de oturan herkes her din, mezhep veya itikadın kamu düzenini ve genel ahlakla çatışmayan gereklerini gerek umumi ve gerekse hususi surette serbestçe icra etmek

\footnotetext{
${ }^{33}$ Kaymaz, a.g.e., s. 338 (1013. Dipnot)

${ }^{34}$ Özdemir, a.g.e., s. 159-160.
} 
hakkına sahip olacaklardır. Gayr-i Müslim azınlıklar, düzenin korunması için memleketin her tarafında tatbik edilen tedbirlere uymak şartıyla serbestçe seyahat etme ve göç hakkına sahip olacaklardır. Bütün Türk halkı din ayrımı yapılmaksızın kanun önünde eşit sayılacak, gayr-i Müslimler de Müslümanlarla aynı hukuk ve siyasete tabi tutulacaklardır ${ }^{35}$.

Azınlıklarla ilgili müzakereler esnasında Nasturilerle ilgili meselenin çözüme ulaştırılamayıp Türkiye-Irak sınırı ile ilgili müzakereler yapılırken tekrar gündeme getirilmesinin yanı sıra Lozan'da Süryanilerle ilgili en ilginç gelişme Lozan Konferansı'nın yapıldığı günlerde Süryani Kadim Patriği 3. İlyas Şakir Efendi'nin Ankara'ya gelmesi olmuştur. Süryani Patriği Lozan'da azınlık haklarının ve özellikle Musul ile ilgili olarak Nasturilerin gündemde olduğu bir dönemde " Biz hukuk-i ekalliyet istemiyoruz." diyerek, Süryani Kadim Cemaati'nin Türklerle birlikte ve aynı statüde yaşama isteklerini ortaya koymuştur ${ }^{36}$.

Süryani Kadim Patriği 3. İlyas Şakir Efendi Yeni Gün Gazetesi’nde Celal Nuri ile yapmış olduğu bir mülakatta da düşüncelerini dile getirmiştir. İlyas Efendi, azınlık hukukunun şimdiye kadar temsil ettiği cemaatin akıl ve hayaline gelmediğini ve gelmesinin de ihtimal dâhilinde olmadığını, Avrupa'nın fuzuli olarak ortaya koyduğu talepleri kabul etmeyerek şiddetle protesto ettiklerini, çok eski zamanlardan beri Süryani Kadim Cemaati'nin Müslümanlarla iyi ilişkiler içinde olduğunu belirtmiştir. İlyas Efendi "Ben cemaatim adına ne böyle bir talepte bulundum ne bulunuyorum ne de bulunacağım" diyerek düşüncesini ortaya koymuştur. Ayrıca cemaatinden aldığı mektupların da bu yönde olduğunu söyleyen İlyas Efendi, Türkiye Büyük Millet Meclisi'nin muvaffakiyeti için dualar ettiğini de sözlerine eklemiştir.

Aynı mülakatta Süryani Kadimlerin Misak-ı Milli hudutları dâhilinde bir ekalliyet olduğunu söyleyen İlyas Efendi, yegâne arzularının iyi günde de kötü günde de ebediyen çoğunlukla yaşamak olduğunu belirtmiştir. Cemaatinin şimdiye kadar hiçbir hususta rencide edilmediğini beyan ederek her fırsatta Türkiye'ye olan bağlılıklarını dile getirmiştir ${ }^{37}$.

${ }^{35}$ Türkiye Dış Politikasında 50 Yıl Lozan (1922-1923), Ankara, Dışişleri Bakanlığı Yayınları, 1973, s. 184. Azınlıkların himayesi ile ilgili diğer maddeler için Bkz. a.g.e., 184187.

${ }^{36}$ Illeri, 9 SSubat 1923.
${ }_{37}$ Yeni Gün, 5 Şubat 1923. Günümüzde Süryanilerin gayr-i Müslim olmalarına rağmen Lozan Barıs Antlaşması'nda gayr-i Müslimlere verilen haklardan yararlanamadıkları yönünde iddialar bulunmaktadır. Baskın Oran, Türkiye'de Azınlıklar Kavramlar, Teori, Lozan, İ Mevzuat, İçtihat, Uygulama, 2. Baskı, İstanbul, İletişim Yayınları, 2005, s. 67-68. Lozan'da Süryanilerin gayr-i Müslim azınlık statüsünde telakki edilmemelerinin sebepleri arasında Osmanlı Millet Sistemi'nde Ermeni, Rum ve Musevilerin en büyük dini gruplar olarak kabul edilmeleri ve küçük gayr-i Müslim toplulukların "Altı topluluk patriği” olarak ifade edilen Ermeni Patrikliği üzerinden devlet ile ilişki kurmuş olmaları gösterilmektedir. Lozan'da Süryaniler Ermeni Patrikliği bünyesinde küçük bir cemaat olarak kabul edilmiş olabilir. 


\section{Musul Meselesi ve Nasturiler}

Yukarıda belirtildiği gibi azınlıklarla ilgili tartışmalarda gündeme gelen Nasturiler Musul meselesinde yeniden gündeme gelmişlerdir. Lozan Konferansı'nda Musul meselesi Ülke ve Askerlik Sorunları Komisyonu'nun 23 Ocak 1923 tarihli oturumunun gündemine alınmıştır. Türkiye Musul'un Türkiye'de kalmasının gerekliliğini savunarak bunu etnografik, siyasi, tarihi, coğrafi ve ekonomik, askeri ve stratejik nedenler olmak üzere beş temel nedene dayandırmıştır. Türk görüşüne göre Musul halkının beşte dördünden çoğunu Türkler ve Kürtler oluşturmaktadır ${ }^{38}$. Ayrıca İngiltere'nin iddia ettiğ i gibi Türklerle Kürtlerin aynı soydan gelmedikleri fikrini de Türk tarafı kesinlikle reddetmiştir. Bölgede bulunan Hıristiyanlar ise Nasturiler, Asuriler ve Keldanilerdir. Türk görüşüne göre Nasturiler, Çarlık Rusyası ordularının Van vilayetini istilası sırasında yüzyıllardır yanlarında huzur içinde yaşadıkları Müslüman yurttaşlara karşı öylesine haince ve kıyıcı olarak davranmışlardır ki, Rusların geri çekilişinde onlarla gitmek zorunluluğunu duymuşlardır. Keldanilere ve özellikle de Diyarbakır vilayetindeki Süryanilere gelince bunlar, dıştan yapılan kışkırtmalara hiçbir zaman kapılmadan Türk yurttaşlarıyla tam bir anlaşma içinde yaşamaktaydılar ${ }^{39}$.

Lozan'da Türk görüşüne göre Musul 11. yüzyıl boyunca aralıksız şekilde Türkiye hâkimiyetinde kalmıştır. Coğrafi olarak Musul iklim ve öteki koşullar bakımından Anadolu'ya eş bir görünümdedir. Akdeniz limanlarına ve Anadolu'ya bağlıdır ${ }^{40}$.

Diğer bir sebep ise İçişleri Bakanlığı'na ait bir genelgenin varlığına dayandırılmaktadır. Adı geçen grupların isimleri bu genelgede geçmediği için ve Süryani hakları akraba bir devlet tarafından takip edilmediği için gayr-i Müslim statüsünde kabul edilmemişlerdir. Ayrıca Süryanilerin kırsal bölgelerde yaşıyor olması nedeniyle haklarını arayamamış olmaları da dikkate alınmaktadır. Omer Ergün, "Lozan’daki Azınlık Anlayıșı ve Süryaniler”, Süryaniler ve Süryanilik, Haz. Ahmet Taşğın, Eyyüp Tanrıverdi, Canan Seyfeli, C. II, Ankara, Orient Yayınları, 2005, s. 251-252. Azınlık haklarının esasen 1500'lü yıllardan beri bireysel hak; yani kolektif olarak kullanıldığ 1 halde gruba değil bireye verilmiş olması, grubun hak sahibi olmaması dolayısıyla bir bireyin hakkından özellikle de bu hak uluslararası bir antlaşmayla getirilmișse ve kaldırılamayacağı açıkça belirtilmişse o bireyin mensubu olduğu grubun lideri ya da temsilcisinin (Patrik Ilyas) feragat edememesi ilkesine dayanarak günümüzde Süryanilerin de azınlık haklarından yararlanmaları gerektiği yönünde iddialar bulunmaktadır Baskın Oran, "Lozan'da Azınlıkların Korunması", Toplumsal Tarih, S. 115, Temmuz 2003, s. 77. Süryani Ortodoks Kilisesi Turabdin Bölgesi Metropoliti Samuel Aktaş da kendisi ile yaptığımız görüşmede bir patriğin kendi cemaati adına bireysel haklardan vazgeçme yetkisinin olmadığını belirtmiștir.

${ }^{38}$ Türk görüşüne göre Musul'da 146.960 Türk, 263.830 Kürt, 43.210 Arap, 18.000 Yezidi, 31.000 Hıristiyan bulunmaktadır. İngiliz görüşüne göre ise 66.000 Türk, 455.000 Kürt, 186.000 Arap, 62.000 Hristiyan ve 17.000 Yahudi bulunmaktadır. Meray, a.g.e., Takım I, C. I, Kitap I, s. 343-344, 358.

${ }^{39}$ Meray, a.g.e., Takim I, C. I, Kitap I, s. 346; Ali Naci Karacan, Lozan, y.y., Milliyet Yayınları, 1971, s. 245.

${ }^{40}$ Meray, a.g.e., Takım I, C. I, Kitap I, s. 350. 
Görüldüğü üzere Türkiye Musul'dan vazgeçmek niyetinde değildir. İngiltere ise Türk görüşünü çürütmek için elinden geleni yapmıştır. Lord Curzon Musul'daki Hıristiyanlarla ilgili olarak; "Ismet Paşa 60.000 kişiyi bulan Asuri ve Nasturi Hiristiyanların meydana getirdikleri topluluklardan söz etmiştir. Bunlar Ankara'ya teslim olmalarını isterler mi? Böyle bir şeyle karşılaşmaktan kendilerini kurtarmak için bana başvuranlardan mektuplar almadığım bir tek gün geçmemektedir. Savaşın başlarında bunlardan binlercesi Çölemerik ve öteki yerlerden uzaklaşarak Türk ülkesinden kaçmıș ve Mezopotamya ovalarına dă̆ılmışlardır; burada onların bakımı için İngiliz Hükümeti yüz binlerce İngiliz lirası harcamak zorunda kalmıştır. Yavaş yavaş onları Musul vilayetinin kuzey bölgelerine yerleştirmeyi başarmiş bulunuyoruz; şimdi orada asker toplayarak kendilerini savunmaya hazırlanmaktadırlar. Bulundukları yerlere kendilerini yerleştiren İngilizlere karşı değil, hiçbir savaş niyeti taşımayan Araplara karşı da değil, Türklerin bir saldırısından korktukları için onlara karşı kendilerini savunmaktadırlar. Türk Temsilci Heyeti'nin beni kendilerine teslim etmeye dostça bir zihniyetle çă̆ırdı ̆̆ insanlar işte bunlardır." demiştir ${ }^{41}$. Görüldüğü üzere İngiltere, önceleri Nasturilerin Türkiye'deki eski yerlerine dönmeleri fikrini savunurken Musul meselesinde onları kullanabilmek adına bu defa onların Türk idaresine girmek istemedikleri fikrini savunmaya başlamıştır.

İngiltere'nin meselenin çözümünün Cemiyet-i Akvam'a bırakılması teklifine karşılık Türkiye'nin bölgede plebisit yapılması teklifi İngiltere tarafından kabul edilmemiştir. Bunu üzerine Lozan Antlaşması'nın 3. Maddesinin 2. Fikrasına göre Türk-Irak hududu dokuz ay zarfında Türkiye ve İngiltere arasında yapılacak görüşmelerin sonucuna bırakılmıştır. Eğer itilaf sağlanamazsa meselenin çözümü Cemiyet-i Akvam'a bırakılacaktı.

Anlaşılacağı gibi Musul'u hiçbir şekilde Türkiye'ye bırakmak istemeyen İngiltere her vasıtayı kullandığ 1 gibi Nasturileri de Musul meselesinde kullanmak istemiştir. Lozan Konferansı'nda çözümlenemeyen Irak sınırı ve Musul meselesi konferans sonrası dönemde Türkiye'nin sıkıntılı bir süreç yaşamasına neden olacaktır.

1923 yılının son aylarında İngiltere'yi Musul'da en çok meşgul eden konu şüphesiz Nasturiler olmuştur. 24 Eylül'de İngiliz Sömürgeler Bakanı, meselenin Cemiyet-i Akvam'a aktarılmadan Türkiye ile ikili görüşmelerde çözüme ulaştırılmasının daha yararlı olacağını Curzon'a bildirmiştir. Ona göre; İngiliz Dışişleri, Musul'un Türklerle aralarında bölüşülebileceğini peşinen kabullenmelidir. Nasturilerin toplu halde başka yerlere göç etmeleri de gündemdedir. Anlaşılan odur ki Sömürgeler Bakanlığı Nasturi meselesinin Türklerle uzlaşmalarını engelleyici bir etken olarak görüşmelere tesir etmesini istememektedir.

\footnotetext{
${ }^{41}$ Meray, a.g.e., Takım I, C. I, Kitap I, s. 360.
} 
Nasturilerin nerelere göç edebilecekleri konusunda bir araştırma yaptıran Sömürgeler Bakanlığı'na gelen cevap Nasturilerin artık Musul'da yaşamak istemedikleri yönündedir ${ }^{42}$. Bununla birlikte Kanada ve Avustralya'nın Nasturileri istemediğini, Meksika, Arjantin ya da Arnavutluk'ta iskân edilebileceklerini düşünen İngiltere, göçe müsaade etmenin Türklere karşı o bölgeden İngiltere'nin vazgeçtiği intibaını vereceği düşüncesiyle Nasturilerin Musul coğrafyasından çıkarılmalarından vazgeçmiştir. Ayrıca İngiltere'nin, Nasturilerin göçüne para ayırmak istemediği de görülmektedir. Irak'taki İngiliz işgal yönetimi de Nasturilerin tümden sınır dışı edilmelerine karşıydı. Çünkü Nasturiler, İngilizler için Irak'taki en önemli vurucu güç unsurlarıydı ${ }^{43}$.

$\mathrm{Bu}$ itibarla İngiltere Dışişleri Bakanlı̆̆ı'nın önünde iki alternatif bulunmaktadır. Ya Nasturilerin Hakkari'ye yerleştirilmeleri için Türkler ikna edilecek ya da Nasturiler, Irak'ta iskân edilip İngiliz himayesine alınacaktır. Curzon, Sömürgeler Bakanlığı'na yazdığı yazıda Nasturileri göç ettirecek paraları olmadığını, onları daha ucuza Türkiye'ye yerleştirebileceklerini, bu işleme derhal başlanıp Türklerin bir oldubitti ile karşı karşıya bırakılması gerektiğini belirtmiştir. Eğer Türkler ikna edilemezse Faysal, Nasturilerin Irak'ın savunması için bulunmaz savaşçılar olduğuna inandırılacaktı ${ }^{44}$. Bağdat İngiliz Yüksek Komiseri Dobbs'a göre de sorunu çözmenin en ucuz yolu Nasturilerin Urmiye ve Van'a yerleşmelerini sağlamaktı. Bu yapılmadan önce adı geçen yerlere onlarla yakından ilgilenecek birer konsolos da atanacaktı. Dobbs Bağdat yönetiminden bölgede kalacak Nasturilere tıpkı Osmanlı Devleti tarafından uygulandığı gibi gevşek bir denetimin sağlanmasını istemiştir. Yani onlar liderlerini seçme ve vergi verme konusunda serbest olacaklardı. Irak, Hristiyanların komşu Kürt aşiretlerine karşı savunulmalarından Irak'ın sorumlu tutulmaması ve onların Irak ile ilişkilerinin bir İngiliz konsolosu aracılığıyla yürütülmesi koşuluyla Dobbs'un teklifini kabul etmiştir.

Dobbs'a göre İngiltere'nin Nasturi politikası Irak ile ilişkilerine zarar vermemeliydi. Çünkü İngiltere'nin Nasturilere karşı bir sorumluluğu yoktu. Onları Türklere karşı ayaklandırıp bu duruma düşmelerine yol açan Ruslardı. İngiltere zaten yıllardır çok fazla para harcayarak Nasturilerin yerleşmelerini ve askeri eğitim almalarını sağlamıştı. Nasturilerin de bundan daha fazlasını istemeye hakkı yoktu ${ }^{45}$.

11 Ekim'de Çal'a doğru Türk birliklerinin ilerlemekte oldukları haberi gelince Türklerin, İngilizlerin Nasturi yurdu projesini icra mevkiine

42 Mim Kemal Öke, Musul Meselesi Kronolojisi (1918-1926), İstanbul, Türk Dünyas1 Araştırmaları Vakfı, 1987, s. 115-116.

${ }^{43}$ Kaymaz, a.g.e., s. 339.

${ }^{44}$ Öke, a.g.e., s. 116-117.

${ }^{45}$ Kaymaz, a.g.e., s. 340. 
koyacaklarını kestirerek bu yöreyi işgal ile projeye engel olacakları düşüncesi İngiltere Dıșişleri’ni endișelendirmiştir. Curzon hemen Türklere şiddetli bir protesto notası çekilmesi talimatı vermiştir.

$\mathrm{Bu}$ arada Ağa Petros oldukça ayrıntılı bir "Nasturi Devleti" planı ile İngiliz Dışişleri'ne başvurmuştur. Planın başında savaştan önce Nasturilerin Müslümanlarla barış içinde yaşadıkları, savaş sırasında müttefiklerin bağımsızlık vaatleriyle silah çekmeye zorlandıkları, Nasturilerin İngiliz subay danışmanlarının gözetiminde Londra'nın emelleri uğruna canlarını verdikleri belirtilmiştir. Bu uğurda 275.000 Nasturi hayatını kaybetmiştir. Bu yardımlarının karşılığ 1 olarak Ağa Petros İngiltere'den Van, Urmiye, Hakkari ve Musul'u içine alan bölgede otonom bir Nasturi yurdunun tesisini istemektedir. Kurulacak bu devlet öncelikle Kuzey Irak'1 Türklerden koruyacak ileride gerektiğinde Kürtlere ve gerektiğinde Araplara karşı İngiltere'nin yakın dostu olacaktı. İngiltere Ağa Petros'un bu taleplerini fazlasıyla iyimser bulmuştu. Bir kere kurulacak olan bu devletin mali açıdan kendi kendine yetebilmesi imkânsız görünmekteydi. Ama yine de değerlendirmeye alınabilir, üzerinde oynama yapılabilirdi.

Nasturi liderleri ise Ağa Petros'un bu teşebbüsünü öğrenmişler ve onunla temasa geçmişlerdi. Onlar meseleye Petros kadar iyimser bakmıyorlardı. Onlara göre İngiltere, Petros'un Musul'a dönmesini hiç istemiyordu. Çünkü Petros, İngiltere'nin Kürt politikasını bozmaktaydı. Şöyle ki; İngilizler Kürtlere bağımsızlık tanımayacaklardı. Petros'un planı uygulanırsa o zaman İngilizler, aynı hakkı Kürtlere de vermek zorunda kalabilirlerdi. Nasturi liderler İngiltere'ye güvenmediklerini Ağa Petros'a açıkça beyan etmişlerdir.

25 Ekim'de Irak Yüksek Komiseri Dobbs, Nasturi meselesini yerinde incelemek üzere Bağdat'tan ayrılmıştır. Diğer yandan Sömürgeler Bakanlığı bu yurt işinin bir an önce çözümlenmesi için Dışişleri Bakanlığı'na baskı yapmaktadır. Meselenin iki bakanlık arasında yapılacak toplantıda çözümlenmesi teklif edilir. Nihayet toplantı tarihi olarak 7 Kasım belirlenir ancak bu tarih 12 Kasım'a tehir edilecek ve o tarih geldiğinde bir kez daha ertelenecektir. Bu arada Dobbs, Musul görüşmelerinde Dışişlerine yardımcı olacak mahiyette İngilizler için en uygun sınır hattını da belirleyen bir muhtırayı Londra'ya gönderir. Dobbs bu metinde İngiltere için savunulacak hattın Nasturilere yurt olarak düşünülen Hakkari'yi de içine alacak şekilde kuzeye doğru kaydırılmasını istiyordu ${ }^{46}$.

İngiltere'nin amacı, Musul'un güvenliğini Nasturi yurdu projesiyle sağlamaya çalışmaktır. Proje başarıya ulaştı̆̆ 1 takdirde bir yandan Nasturiler, İngiltere için maddi bir yük olmaktan çıkacak öte yandan bu insanlar

\footnotetext{
${ }^{46}$ Öke, a.g.e., s. $117-119$.
} 
isteklerine kavuşmuş olacaklardır. Ancak İngiltere için bunlardan daha önemlisi Musul sınırı, kurulacak olan Hıristiyan bir tampon devlet tarafından Türklere karşı korunmuş olacaktır ${ }^{47}$.

\section{Haliç (İstanbul) Konferansı}

İngiltere'nin Lozan Konferansı'ndan itibaren Musul meselesinin çözüme kavuşturulmasını istemediği aşikârdı. Bu yüzden hiçbir gayret sarfetmeyen İngiltere, farklı talepler ortaya atarak meseleyi adeta yokuşa sürmüştür. İngiltere esasen ikili görüşmelere sıcak bakmamaktadır. Nasıl olsa mesele Cemiyet-i Akvam'a bırakılacaktır. İngiltere'nin ikili görüşmeleri kabul etmesinin sebebi ise bir siyasi manevradır. İngiltere meselenin bir anlamda biraz küllenmesini istemiştir. Bunun sebeplerinden birisi bazı devletlerin desteğini almasına karşılık henüz tam anlamıyla dünya kamuoyunun desteğini alamamış olmasıdır. Ayrıca İngiltere Mezopotamya'daki hâkimiyetini henüz meşrulaştıramamışt1; yani Irak Meclisi'nin İngiltere'nin mandaterliğini kabul etmemiş olması İngiltere'yi Irak'ta sömürgecilik siyaseti yapan bir ülke konumuna getirmişti. Tüm bunlar İngiltere'nin şartların biraz daha olgunlaşmasını beklemesi için gerekli sebeplerdendi ${ }^{48}$. Ancak yine de İstanbul'da gerçekleştirilecek olan görüşmelere İngilizler hazırlıklı geleceklerdir.

İngiltere konferans öncesinde taktiğini şu şekilde belirlemişti; Musul'un Irakla birleşmesinde israr edilecek ve Nasturiler için de Türkiye'den Hakkari istenecektir. Türkiye itiraz edecek olursa taviz verilmemeli ve mesele Cemiyet-i Akvam safhasına bırakılmalıdır ${ }^{49}$. Aslında İngiltere, Musul'un tamamında hak iddia eden Türkiye'nin bu teklifi kabul etmeyeceğini çok iyi biliyordu. İngiltere için önemli olan nokta; mesele Cemiyet-i Akvam'a getirildiğinde İngiltere'nin Nasturilerin yerleştirilmeleri için tamamen insancil nedenleri olduğu, Türkiye'nin ise bunu kabul etmediği izleniminin yaratılmasiydi ${ }^{50}$.

19 Mayıs 1924 tarihinde başlayan konferansta her iki taraf da yine kendi görüşlerinde 1 srar etmişlerdi ${ }^{51}$. Türk heyeti Musul'u Türk tarafına bırakacak şekilde sınırın çizilmesini talep ederken İngiltere buna karşılık konferansın üçüncü oturumunda Musul'un yanı sıra Hakkari vilayetini de istemiştir. İngiltere, Hakkari’yi isteyerek Türk-Irak sınırı konusundaki

\footnotetext{
${ }^{47}$ Anzerlioğlu, Nasturîler, Ankara, Tamga Yayıncılık, 2000, s. 127.

${ }^{48}$ Tahir Kodal, Paylaşılamayan Toprak Türk Basınına Göre Musul Meselesi (19231926), İstanbul, Yeditepe, 2005, s. 170-171.

${ }_{49}$ Öke, a.g.e., s. 129.

${ }^{50}$ Kaymaz, a.g.e., s. 353

${ }^{51}$ Konferansta İngiltere'yi Sir Percy Cox'un yanı sıra C.H. Jardine, J. H. Hall ve Yarbay F. W. Lees temsil ederken Türkiye'yi TBMM Baskanı Fethi Bey, Diyarbakır Mebusu Feyzi Bey, Ordu Mebusu Faik Bey, Dışişleri Hukuk Müşaviri Nusret Bey ve Genelkurmay'dan Albay İshak Hayri Bey temsil etmiştir. Anzerlioğlu, a.g.e., s. 127.
} 
önerisini daha da kuzeyden geçecek bir çizgi olarak öne sürmüş oluyordu. İngiltere'nin, Türkiye'nin kabul edemeyeceği istekler öne sürerek sorunun Cemiyet-i Akvam'a götürülmesini sağlamayı planlamış olma ihtimali oldukça yükssektir ${ }^{52}$. Ayrıca Hakkari ve çevresine Nasturileri yerleştirmek suretiyle bir tampon bölge oluşturmak İngiltere'nin önemli hedeflerinden biriydi.

Türk heyeti başkanı Fethi Bey (Okyar) ise İngiltere'nin isteklerine karşılık olarak Dünya Savaşı'nın başlangıcında Nasturilerin dış kökenli tahriklere kapılarak yaptıkları hatayı tekrarlamadıkları takdirde Türk topraklarında huzur içinde yaşayabileceklerini dile getirmiştir ${ }^{53}$. Fethi Bey ayrıca bu yeni isteğin Lozan Antlaşması'nın 3/2. Maddesine aykırı olduğunu, söz konusu vilayette Nasturilerin sayısının oldukça az olduğu göz önüne alınacak olursa azınlığın çıkarları için çoğunluğun haklarının ikinci plana atılmasının yanlış olduğunu ve Nasturilerin yaşadıkları sorunların tek sebebinin Osmanlı Devleti'ne karşı silahlı ayaklanmaya kalkışmaları olduğunu ifade etmiştir ${ }^{54}$.

Sonuç olarak Haliç Konferansı'nda bir çözüme ulaşılamamış ve 5 Haziran'da konferans tatil edilmiştir. Görüldüğü üzere İngiltere'nin temel amacı Musul meselesinin çözümünde ağır davranarak meseleyi Cemiyet-i Akvam'a havale etmektir. Haliç Konferansı'nda ortaya konulan Nasturi yurdu meselesi ise İngiltere'nin bölgedeki güvenliğinin sağlanması amacıyla ortaya atılmıştır. Buna göre; Hakkari bölgesi İngiltere himayesinde olmak üzere Nasturilere verilecek ve Irak'a bağlanacaktı. Böylelikle savaşçılıklarıyla da bilinen bu topluluk Musul'un güvenliğini sağlamak maksadıyla stratejik bir mevkie yerleştirilmiş olacaktı. Nitekim Konferans sonrasında Fethi Bey'in Cumhuriyet Gazetesi'ne yaptığı şu açıklama da bu görüşümüzü destekler niteliktedir: "...Ingiltere, orada sakin bulunan ve ekalliyet-i gâlileyi teşkil eden Hiristiyanlar ki bunlar da Nasturilerden ibarettir hudut üzerinde ikame ederek, bu suretle İslam anasirl arasinda bir mani'a vücuda getirmek amacındadır.",55

Ali Fethi Bey Türkiye'nin bu konudaki görüşünü de şu şekilde açıklamıştır: "Nasturilerin Harb-i Umumi zamanında Rus istila orduları tarafindan yapılan tahrikata kapılmaları ve vatandaşları aleyhine silahlı ayaklanmada bulunmaları neticesinde uğradıkları felaket kendileri ve Ingiltere Hükümeti için bir ders-i ibret olmak lazım gelir. Nasturiler ancak

${ }^{52}$ Ömer Kürkçüoğlu, Türk-İngiliz İlişkileri (1919-1926), Ankara, AÜSBF Yayınları, 1978, s. 292.

${ }_{53}$ Milletler Cemiyeti Belgelerinden Musul Kerkük Sorunu ve Kürdistan'ın Paylaşımı, Milletler Cemiyeti Tarafindan 30 Eylül 1924 Tarihinde Oluşturulan Komisyonun Raporu, 2. Bask1, İstanbul, Med Yayınc1lık, 1991, s. 216.

${ }_{55}^{54}$ Kaymaz, a.g.e., s. 355-356.

${ }^{55}$ Cumhuriyet, 10 Haziran 1924. 
sakin bulundukları memleket halkına karşı düşmanca vaziyet almakla değil, belki onlarla iyi geçinmek suretiyle müessir surette himaye etmiş olurlar." ${ }^{\text {"6 }}$

Türkiye her ne kadar meseleyi barışçı yollarla çözmeye çalıştıysa da İngiltere sürekli kendi çıkarlarını düşünerek hareket etmekteydi. Haliç Konferansı'nın dağılması meselenin Cemiyet-i Akvam'a havale edilmesi anlamına geliyordu. Ancak İngiltere, bu aşamada da bir manevra yapacak zaten yıllardır kullandığ 1 Nasturileri bir kez daha kullanmaktan çekinmeyecekti. Böyle bir dönemde ve ortamda çıkacak bir Nasturi isyanı İngiltere'nin elini güçlendirecekti.

\section{Nasturi İsyanlart}

İngiltere Lozan Antlaşması'nın 3. Maddesinin 2. Fıkrasına göre hareket ederek Musul meselesini Cemiyet-i Akvam sürecine sokmuş ve 6 Ağustos 1924 'te Cemiyet-i Akvam Konseyi'ne başvurmuştur. Ancak İngiltere Musul meselesinde Türkiye'yi güçsüz bırakma planı dâhilinde Nasturilerden de yararlanma yolunu tutmuştur.

$\mathrm{Bu}$ meyanda olmak üzere İngiltere, Irak'taki Ermeni ve Nasturileri silahlandırarak Kerkük, Erbil ve Revandız dolaylarında toplayıp Türklere karşı önemli bir kuvvet meydana getirmeye çalışmaktaydı.

Türk hükümeti ise onların bu faaliyetlerine karşılık olarak statüko sınırı dışında propaganda yapılmasına, aşiretlerden özel teşkilat kurarak Musul dâhilinde yapılacak propaganda faaliyetlerinin arttırılmasına karar vermiști. Türkiye'nin bunda maksadı İngilizlerin Nasturileri kullanarak Hakkari'yi elde etmeye çalışmasını önlemek, Musul sorunu Cemiyet-i Akvam'da görüşüldüğüi sırada İngilizlerin Haliç Konferansı'nda tespit ettikleri sınırın Irak'a ait olduğunu iddia etmeleri dolayısıyla buraları işgal suretiyle Nasturi tehlikesini bertaraf etmektir ${ }^{57}$.

Türk hükümetinin Nasturilere karşı tedbirler almayı düşündüğü bu günlerde Nasturiler de büyük çapta bir isyan hareketine kalkışmışlardır. Bu hareketin ilk ayağını da Hakkari Valisi Halil Rıfat Bey ve beraberindekilerin 7 Ağustos 1924'te Hangediği denilen yerde kaçırılması teşkil etmiştir. Çal Nahiyesi'ne (Çukurca) gitmek üzere merkez vilayetten hareket eden vali ve beraberindekiler Nasturiler tarafından pusuya düşürülmüşler, Jandarma Kumandanı ve erlerden bazıları şehit düşerken Halil Rıfat Bey ve diğer jandarmalar esir edilmişlerdi ${ }^{58}$.

Vali Halil Rıfat Bey'in daha sonra anlattıklarına bakılacak olursa olayı Nasturi Tohup Aşireti mensupları düzenlemiştir. İmadiye’ye götürülmeye

\footnotetext{
${ }_{57}^{56}$ Cumhuriyet, 10 Haziran 1924.

7 Reşat Hallı, Türkiye Cumhuriyetinde Ayaklanmalar (1924-1938), Ankara, Genelkurmay Basımevi, 1972, s. 26-27.

${ }^{58}$ Hakimiyet-i Milliye, 13 Ağustos 1924.
} 
çalışılan vali ve beraberindekiler Aşağ Hoşabe'nin duruma müdahalesi sonucu serbest bırakılmışlardır. Burada en dikkat çekici nokta; Nasturilerin İngiliz terbiyesi almış gibi davranmaları ve onların arasında üniformalı İngiliz askerlerinin dolaşmasıdır. Bu durum İngilizlerin Nasturileri kışkırttığını göstermektedir ${ }^{59}$. Musul meselesinin tam da Cemiyet-i Akvam'a bırakılmasının ertesi günü böyle bir hadisenin gerçekleşmesi bir tesadüf olmasa gerektir. Ayrıca Çal'ın Türkiye tarafından atanmış Nahiye Müdürü Ulia/Evliya Bey'in olaydan hemen sonra İngilizlerle beraber kaçması da düşündürücüdür ${ }^{60}$.

Haliç Konferansı'nda Hakkari'yi Nasturiler için isteyen İngiltere bunda başarılı olamayınca Nasturileri ayaklandırarak kamuoyunda Türk Hükümeti'nden memnun olmadıkları izlenimi yaratmış ve bu durumda idarelerinin Türklere bırakılmasının doğru olmadığı fikrini kabul ettirmeye çalışmı̧sırı.

Gerçekten de The Times Gazetesi'nde yayınlanmış bir yazıdan da durumun böyle olduğu anlaşılmaktadır. Bu yazıda Nasturiler için istenen Türk toprakları Asuriye Eyaleti olarak belirtilmiş ve Hakkari'de meydana gelen olaya atıfta bulunularak eğer bu bölge Türkiye'ye bırakılacak olursa daha çok hadiselerin gerçekleşeceği ifade edilmiştir. Yine aynı yazıda Türk toprağ 1 olan Çölemerik henüz kimseye ait olmayan topraklar olarak adlandırılmış ve bu bölgeyi teftişe çıkan Vali Halil Rıfat Bey sanki bu topraklara tecavüzde bulunmuş izlenimi yaratılmaya çalışılmıştır ${ }^{61}$. Bu durum şüphesiz Türkiye'nin operasyon fikrini tetiklemiştir.

Yapılması gereken harekât hakkında 3. Ordu Müfettişliği'nin de fikrini alan Genelkurmay Başkanlığı, 13 Ağustos 1924'de Başbakanlığa sunduğu raporunda özetle; tedibi düşünülen Nasturilerin, Beytüşşebap ve Çölemerik'in güneyi, Oramar ve Çal'ın batısı, İmadiye'nin güneyi, Gılıgoyan Aşireti ve Merinar Dağı'nın çevirdiği bölgede yaşadıkları, sayılarının 8000 olup 1000 kadar silahlı çıkaracakları haberinin alındığı belirtildikten sonra Nasturilerin direnmeden göç etmeleri ve tek başlarına karşı koymalarının uzak olasılıklar olduğu keza İngiltere'nin olaya fiilen katılmasının da Türkiye ile İngiltere arasında savaş ilanı olacağından buna ihtimal verilmediği ifade edilmiştir. Genelkurmay aynı raporunda alınması gereken önlemleri ayrıntılı olarak sıralamıştır ${ }^{62}$.

14 Ağustos 1924'te toplanan Bakanlar Kurulu kararına göre; Nasturi hareketinin bastırılması için Genelkurmay Başkanlığı memur edilmiştir.

${ }^{59}$ Hallı, a.g.e., s. 28-29; Vedat Şadillili, Türkiye'de Kürtçülük Hareketleri ve İsyanlar, C. I, Ankara, Kon Yayınları, 1980, s. 60-61.

${ }^{60}$ Hakimiyet-i Milliye, 9 Teşrini Evvel 1924; Kaymaz, a.g.e., s. 400-401.

${ }^{61}$ İkdam, 21 Eylül 1924.

${ }^{62}$ Hallı, a.g.e., s. $30-32$. 
Yayınlanan bir kararname ile de Nasturi hareketleri ile ilgili teşkilat ve icraatın idaresi 7. Kolordu Kumandanlığı'nın mesuliyetine verilmiş ve bu kolordunun haberi olmadan bölge valilerinin harekette bulunmaması istenmiştir ${ }^{63}$. Harekatın hızla yapılması, statüko sınırına tecavüz edilmemesi bölge aşiretlerinden özellikle de Ağa Simko'dan yararlanılması kararlaştırılmıştır ${ }^{64}$. Hükümet Ağa Simko'dan özellikle İran sınırında meydana gelebilecek olaylarda ve İran'da bulunan Nasturilerin Türkiye'dekilerle birleşmesinin önlenmesi için yararlanmayı düşünmüştür ${ }^{65}$. Onun vasıtası ile Revandız alınacak ve İngiltere ile mücadelesine devam eden Şeyh Mahmut'la bağlantı kurulacaktı ${ }^{66}$. Aynı tarihte İngiltere de bir muhtıra vererek Nasturilerin Türk idaresinde gördüğü baskılar sonucunda Birinci Dünya Savaşı'nda müttefiklerin safında yer aldığını, bu kararı yüzünden büyük acılar çekip yurtlarından sürüldüğünü ve onların eski topraklarında ya da hiç olmazsa bölgeye komşu topraklarda İngiliz koruması altında yerleşmek istedikleri iddialarını tekrarlamıştır. Bu muhtırada İngiltere ayrıca eğer sınırın istenilen şekilde çizilmesi sağlanamazsa Nasturilerin savaş seçeneği dışında başka bir seçeneğe sahip olmayacağını bunun da bir ölçüde barış ve refahı tesis etmeyi imkânsız kılacağını dile getirmiştir $^{67}$. Görüldüğü gibi İngiltere bir yandan meselenin barışçıl yollarla çözülmesi taraftarıymış gibi görünürken diğer yandan adeta bir anlamda gözdağı vermektedir.

$\mathrm{Bu}$ arada Genelkurmay Başkanlığı 7. Kolordu Kumandanı Cafer Tayyar Paşa'yı isyanı bastırmakla görevlendirmiştir. Cafer Tayyar Paşa, 23 Ağustos 1924'te Genelkurmay'a harekâtla ilgili sunduğu bir raporda erlerin çoğunun yeni olması ve bir muharebeye iştirak etmiş kimsenin bulunmaması sebebiyle eğitim yapılmasının gerekliliğini dile getirmekteydi. Eldeki kuvvetlerle Nasturilerin tedibi sağlanabilirdi. Ancak Nasturiler Musul'dan takviye aldıkları takdirde durum oldukça güçleşebilirdi ${ }^{68}$.

Genelkurmay Başkanlığı'nın bu haber üzerine görüşleri ise şöyleydi: 20 gün sonra Türkiye'nin Cemiyet-i Akvam'da Musul sorununu müzakereye katılması zorunlu idi. Bundan dolayı bu süre geçmeden başarı kazanılması lazımdı. Aksi takdirde yargının aksi olarak tedibata kalkışmak gerekecekti ki bu da büyük bir siyasi güçlük doğuracaktı. Bu itibarla harekâta buna göre başlamak ve bitirmek gerekmekteydi.

6 Eylül 1924'te Genelkurmay 7. Kolordu'ya bir emir daha verdi. Bu emirde; “...yapılacak harekâtın bütün Nasturileri tedip için değil sadece

\footnotetext{
${ }^{63}$ BCA, Fon Kodu: 30/18.01.01, Yer No. 10.32.1.

${ }^{64}$ Hallı, a.g.e., s. 33.

${ }^{65}$ Kodal, a.g.e., s. 251

${ }^{66}$ Kaymaz, a.g.e., s. 401

${ }^{67}$ Milletler Cemiyeti Komisyon Raporu, s. 219-220.

${ }^{68}$ Hallı, a.g.e., s. 37.
} 
Hakkari'nin güney sınırını isgal ve Hakkari valisine taarruz eden çeteyi tedip maksadiyla olacă̆ c cihetle, askerimize karşı iyi niyetle hareket eden ve silah atmayan her şahsin iyi muamele göreceği ve yakalanacak olan çetenin Cumhuriyet Hükümetimizin kanunlarına göre adalete teslim edileceğ̈i" belirtilmekteydi ${ }^{69}$.

$\mathrm{Bu}$ sırada İngiltere de boş durmuyordu. İngilizler, Birinci Dünya Savaşı'nda yaptıkları gibi Nasturilere her türlü destek sözü vermişlerdir. Hatta Mister Lloyd adlı bir İngiliz memuru Çal nahiyesine gelerek Nasturileri kışkırtmaya çalışmış ve Türkiye Hükümeti'nin bazı uygulamalarına itiraz etmek gibi garip tavırlarda bulunmuştur ${ }^{70}$. İngilizler vermeye çalıştıkları bu desteklerin sonuçlarını kısa sürede almış harekâtın başladığı günlerde ordu içinde huzursuzluklar meydana gelmiştir. Beytüşşebap'ta bir yüzbaşı, bir teğmen beraberindeki erlerle beraber bulundukları yerlerden ayrılarak firar etmişlerdir ${ }^{71}$.

Artık kaçınılmaz hale gelen harekât 12 Eylül 1924'te başlamıştır. Oluşturulan planına göre hareket eden ordunun faaliyetlerinin yanı sıra diplomatik faaliyetler de devam etmekteydi. Türkiye, İngilizlerin Nasturileri kullanarak Türk topraklarına tecavüz etmeleri üzerine, Lozan Antlaşması'nın ihlal edildiği gerekçesiyle 17 Eylül 1924'de Cemiyet-i Akvam'a bir nota vermiştir ${ }^{72}$.

21 Eylül'de Genelkurmay Başkanlığı da İngiltere'ye sert bir ültimatom vererek saldırıların sürmesi halinde Türkiye'nin statükoya uyma yükümlülüğünün ortadan kalkacağını bildirmiştir. Eğer İngiltere saldırılarını sürdürmeye devam ederse Musul'u işgal etmek için yeni bir operasyon planı hazırlanacaktı ${ }^{73}$.

Genelkurmay Başkanlığı İngilizlerin böyle sert bir tepki karşısında tecavüzden vazgeçecekleri kanısında idi. Zira Genelkurmay Başkanlığı İngilizlerin Mısır, Sudan, Irak ve Hicaz'da elverişsiz bir durumda olmaları sebebiyle Musul meselesinin hallinde Türkiye ile bir harbi göze alabileceğini sanmıyordu. Bununla birlikte İngilizlerin tecavüzde ssrarcı olmaları ihtimali de göz önüne alınarak sadece Zaho ve İmadiye'nin işgali ile yetinilmemesi ve İngilizlerin Musul'dan tamamen atılıncaya kadar harekâtın genişletilmesi düşünülmüşsür ${ }^{74}$.

\footnotetext{
${ }^{69}$ Hall1, a.g.e., s. 41-43.

${ }^{70}$ TBMM Zabit Ceridesi, 2. Dönem, 1. İçtima, 1. Celse, 18.10.1340, C. IX, s. 10

${ }^{71}$ Anzerlioğlu, a.g.e., s. 146.

${ }^{72}$ Cumhuriyet, 19 Eylül 1924.

${ }^{73}$ Kaymaz, a.g.e., s. 402-403.

${ }^{74}$ Ücüncü Ordu Bölgesinde Çıkan Ayaklanmalar ve Ayaklanmaların Bastırılması, Haz. Kemal Yilmaz, Ankara, 1991, s. 35-36.
} 
Bu arada Nasturilere karşı yapılan harekât da hızla devam etmekteydi. 24 Eylül'de Nasturiler birçok yerden kaçmak zorunda kalmışlardı. Genelkurmay Başkanlığı 2 Ekim'de verdiği emirde ise Zap'ın doğusunda kimse kalmadığına göre tedip harekâtının fiilen sona erdiğini bildirmiştir.

Harekâtın sona ermesi dolayısıyla kıtalara yeni tertipler aldırılırken Ankara'da da temaslar devam etmekteydi. Karşıllklı nota teatileri suretiyle devam eden siyasi faaliyetler sonunda meselenin Cemiyeti-i Akvam'da halli yolunda mutabık kalınmıştı. Bu arada TBMM toplanarak gereken kararı vermiş olduğu için Genelkurmay Başkanlığı 19 Ekim 1924'te geçici olarak kurulan tertibatın kaldırılmasını harekâtın sorumluluğunu uhdesine almış olan 3. Ordu Müfettişliği'ne bildirmiştir. Genelkurmay Başkanlığı Hakkari harekâtının sona ermesi dolayısıyla harekâta katılan birliklerin yeni yerlerini de belirlemiştir. Siyasi halin şimdilik belirsiz olduğunu kabul eden Genelkurmay Başkanlığı Musul meselesinin kesin surette halline kadar 3. Ordu Müfettişliğ̈i'nin Diyarbakır'da kalmasını uygun görmüştürr ${ }^{75}$.

Nasturilerin bu ayaklanma hareketi esnasında İngiltere'yi en çok rahatsız eden nokta isyanın bu kadar çabuk bir şekilde bastırılmış olmasıdır. Yüzbaşı Lloyd'a göre Nasturiler, İngilizleri bir "Nasturi Devleti” kurmaya zorlamak adına bilinçli olarak böyle davranmışlardır. Dobbs ise eğer Lloyd'un bu tespiti doğru ise Nasturilerin İngiltere'nin tüm desteğini kaybedeceklerini onları bir bölgeye yerleştirme fikrinden ve bu konuda para harcamaktan vazgeçilmesi gerektiğini düşünmekteydi. Ancak Irak'taki bu İngiliz yetkililerinin gözünden kaçan unsur; geçmişte Arap ve Kürtlere karşı başarılı olan Nasturilerin düzenli ordu birlikleri karşısında aynı başarıyı gösteremeyecek olmalarıydı. Küçük çaplı ayaklanmaları bastırmakla düzenli ve planlı ordularla mücadele etmenin aynı olmayacağ 1 bir gerçekti. İngiltere'nin sergilediği bu tutumla artık Nasturileri gözden çıkartmak için bahaneler yaratmaya çalıştığını söylemek yanlış olmasa gerektir ${ }^{76}$.

\section{Cemiyet-i Akvam Görüsşmeleri}

İngiltere 6 Ağustos 1924'te Cemiyet-i Akvam Konseyi'ne başvurarak Musul meselesinin, yapılacak olan ilk toplantının gündemine alınmasını istemişti. Bu başvurudan sonra da bir muhtıra veren İngiltere, Nasturilerin Türk yönetimini istemediklerini ve onların eski topraklarını kapsayacak bir sınırın çizilmesi talebinde bulunduklarını ifade etmişti. Bu başvuruyu alan Cemiyet-i Akvam 19 Ağustos'ta Türk Hükümeti'ne bir mektup göndererek İngiltere'nin isteğini bildirmiş ve Türkiye'nin cevabını istemişti. Ancak Türkiye o sırada Nasturi isyanı ile uğraştı̆̆ için hemen cevap vermemiştir.

\footnotetext{
${ }^{75}$ Halli, a.g.e., 73-74

${ }^{76}$ Kaymaz, a.g.e., s. 403-404.
} 
Türkiye'nin cevabı 27 Ağustos'ta Cemiyeti-i Akvam'a ulaştırılmış ve görüş̧melere yirmi gün zarfında iştirak edileceği bildirilmiştir ${ }^{77}$.

Nihayet 5 Eylül'de Türk heyetinin muhtırası konsey üyelerine dağıtılmıştır. Bu muhtırada İngiliz iddialarına karşı Türk tezi savunuluyordu. Türkiye plebisit yapılması isteğinde ısrar ediyordu. Nasturilerle ilgili olarak Türk heyeti; “Britanya Hükümeti'nin Musul vilayetinin gayr-i Müslimleri arasında savas sirasında müttefiklerin tarafinı tutanlara beslediği sempati ne olursa olsun, bu sempati, bu topluluğun nüfusun ancak 1/17'ini oluşturduğu bir büyük vilayetin Türkiye'den ayrılmasını haklı çıkarmayacaktır. Bu Asurlu Nasturilerin kökeninin Musul değil Hakkari vilayeti olduğu düşünülürse bu haksızlık daha da büyümektedir. Ĕ̆ger savaş sirasında doğdukları toprakları terk etmek zorunda kaldılarsa bunun nedeni Müslüman yurttaşlara karşı silaha davranmış olmalarıdır...Britanya Hükümeti'nin Asurlulart yoğun bir kitle halinde Türkiye-Irak sinırl yakınına yerleştirme amacı bu topluluğun istemleri ne olursa olsun amacın gerçekten bu mu oldu $\breve{g} u$ yoksa bu önerinin ardında başka nedenler mi bulunduğu konusunda akla sorular getirmektedir. Bu Asurluların Kürtlere karşı kullanılabilecek ve Türkiye'ye karşı saldırgan amaçlar canlandıracak böylesi yapay bir toplaşmasi Britanya Hükümeti'nin elde etmeyi umduğu sonuçları kesinlikle yaratmayacaktır." demiştir ${ }^{78}$. Görülüyor ki Türkiye İngiltere'nin oynamaya çalıştığı oyunun farkındadır ve bu oyunu bozabilmek için elinden geleni yapacaktır.

14 Eylül 1924'de Cenevre'ye ulaşan Türk heyeti, 23 Eylül'de Cemiyet-i Akvam Genel Sekreterliği'ne bir nota daha vererek Londra ile aralarındaki diplomatik münasebetlerin yeniden başlamasına rağmen İngiliz uçaklarının sınırı geçip, Türk topraklarını bombaladığı şikâyetinde bulunmuştur. 9, 12 ve 14 Eylül'de gerçekleştirilen bu hava saldırısında üç Türk hayatını kaybetmiş, 12 asker de yaralanmıştı. Söz konusu saldırının tesadüfen olmadığı, gizli bir planın parçası olduğu iddiasında bulunan Türkiye, İngiltere'nin Nasturileri tahrik edip isyana sevk ettiğini de bildirmiştir. İngiltere sınırda kasti olarak kargaşa çıkararak statükoyu bozma yoluna gitmekteydi ${ }^{79}$. Ertesi gün buna cevap veren İngiltere, Türk birliklerinin statüko sınırını geçtiklerini ileri sürmüştür. Türkiye ise statüko sınırının kesinlikle ihlal edilmediğini bildirmiştir.

Bu tecavüzler olurken Cenevre'de de müzakereler devam etmekteydi. Nihayet 30 Eylül'de Musul meselesini inceleyecek bir komisyonun

\footnotetext{
${ }^{77}$ Kodal, a.g.e., s. 255.

${ }^{78}$ Milletler Cemiyeti Komisyon Raporu, s. 220-221.

${ }^{79}$ Öke, a.g.e.,, s. 142-143; Cengiz Kürşad, "Cumhuriyetimizin Korunması (II) Nasturi İsyanları”, Belgelerle Türk Tarihi Dergisi, S. 41, Temmuz 1988, s. 28-30.
} 
kurulmasına karar verilmiştir. Bu komisyon tarafsız devletlerden seçilen üç kişiden oluşacaktı ${ }^{80}$.

Daha Türk heyeti Ankara'ya dönmeden İngiltere 5 Ekim'de bir nota daha yayınladı. Bu notada Türkiye'nin statüko hududunun haricine çıkması isteniyordu. İngiltere'nin buradaki tezi şöyleydi; Türkiye hem Musul vilayeti haricine hem de Nasturilere karşı harekât yapılan mıntıkadan çıkacaktı. Hakkari vilayetinin güneyi yani Beytüşşebap ve Çölemerik mıntıkası Lozan Antlaşması imza olduğunda İngiltere'nin işgalinde değildi. Fakat Türkiye'nin de işgalinde değildi ${ }^{81}$. İngiltere bu nota ile Türkiye'nin Nasturilere karşı gerçekleştirmiş olduğu harekâtın Türkiye sınırları içinde olduğunu görmezden gelerek bir anlamda Türklerden kendi topraklarını boşaltmasını istemiştir ${ }^{82}$.

Öte yandan Musul bölgesinde Türkiye ve İngiltere arasında sınır çatışmalarının artması ve gerginliğe yol açması üzerine Cemiyet-i Akvam Konseyi, 27 Ekim 1924'te Brüksel'de olağanüstü toplanmaya karar vermiştir.

Türkiye'nin Cemiyet-i Akvam konseyinin tarafsız olarak bir karar vereceğine olan inancına karşılık konsey ertesi gün İngiliz yetkililerinin de bulunduğu gizli bir toplantı yapmış ve Türkiye'ye verilecek cevabı kararlaştırmıştır. Bu gizli görüşmede de İngiltere yine Nasturilerle ilgili olarak aynı görüşlerini dile getirmiştir. Türk hükümetinin Nasturi yerleşim bölgesine olan müdahalesini statüko ihlali olarak nitelemiştir ${ }^{83}$.

Sonuç olarak "Brüksel Hattı" geçici sınır olarak kabul edilmiştir. İngiltere'nin ise Nasturi tampon bölgesini kuramasa da amacına bir anlamda ulaştığı söylenebilir ${ }^{84}$.

$\mathrm{Bu}$ arada Musul Komisyonu da 13 Kasım'da çalışmalarına başlamıştı. Komisyon Bağdat ve Musul'da incelemelerde bulunduktan sonra hazırladığı raporu 16 Temmuz 1925'te Cemiyet-i Akvam'a sunmuştur. Komisyonun raporuna göre; Brüksel Hattı coğrafi sınır olarak benimsenmiş ve Musul vilayetinin Irak’a bırakılmasının en iyi çözüm olduğu bildirilmiştir. Diğer yandan İngiltere'nin Hakkari üzerindeki iddiası kabul edilmemiştir ${ }^{85}$.

${ }^{80}$ Komisyon Macar eski Başbakanı Kont Teleki, Belçikalı Albay A. Paulis, İsveç Bükreș Büyükelçisi De Virsen'den oluşmaktaydı.

${ }^{81}$ TBMM Zabut Ceridesi, 2. Dönem, 1. İçtima, 1. Celse, 18.10.1340, C. IX, s. 8.

${ }^{82}$ Kodal, a.g.e., s. 277.

${ }^{83}$ Kaymaz, a.g.e., s. 418-419.

${ }^{84}$ Kodal, a.g.e., s. 286.

${ }^{85}$ Komisyon ayrıca Musul vilayetinin çoğunluğunu sayıları 500 bin kadar olan Kürtlerin oluşturduğu ve bunların irk olarak Türk ve Araplardan farklı oldukları, iktisadi olarak bölgenin Irak'a bağlanması gerektiği, Irak'taki manda yönetiminin en geç 1928'de sona ereceği için bu yönetimin 25 yıl uzatılması ve Musul'daki Kürtlere idari ve kültürel haklar verilmesi kaydıyla Komisyon, Cemiyet-i Akvam Meclisi, Musul vilayetinin Türkiye ile Irak 
Komisyon çalışmalarını yaparken İngiltere, komisyonu Nasturilerin geleceğinin bu sınır tespitine bağlı olduğuna inandırmaya çalışmıştır. Komisyon üyeleri bölgeyi terk ettikten sonra Musul halkına karşı tutumlarını sertleştiren İngiltere, Brüksel Hattı'na Nasturileri yı̆̆arak bunları silahlandırmış hatta onların önünü açmak maksadıyla bölgede yeniden bombalama faaliyetlerine girişmiştir ${ }^{86}$. Komisyon Nasturilerle ilgili olarak en iyi çözümün Haliç Konferansı'nda Türkiye'nin teklif ettiği eski yerleşim yerlerine dönmeleri olacağını bildirmiş buna ek olarak da geçmiște faydalandıkları yerel özerkliğe sahip olmaları ve genel bir afla güvenliklerinin garanti edilmesi gerektiğini de belirtmiştir ${ }^{87}$. Komisyon, Nasturilerin hangi devletin hâkimiyeti altında olurlarsa olsunlar kendi memurlarını aralarında tayin etmek hakkına sahip olarak ve onlardan patrikleri vasıtasıyla vergi almak kosuluyla bir dereceye kadar mahalli bir muhtariyet temin edilmesini istemişti ${ }^{88}$. Ayrıca komisyon Nasturilerin Musul'a yerleştirilmelerini kabul ediyordu. Bu durum yöre ahalisi içerisine Türk aleyhtarı bir grubun daha monte edilmesi sonucunu doğurmaktaydı. Bu da komisyona Musul'un Türkiye'ye bırakılmaması için bir sebep sağlayacaktı. Zaten İngiltere'nin de istediği buydu. Aslında Londra'nın usta diplomatlarının Nasturi meselesini ortaya atma gayesi, bu bahane ile meseleyi farklı bir alana kaydırarak Musul meselesinin İngiltere lehine çözümüne olanak sağlamaktı ${ }^{89}$.

Esasen Nasturiler Türkiye sınırları içerisindeki eski yerlerine döndükleri ve Türk hükümetine bağlı oldukları takdirde hiçbir sorunla karşılaşmadan güven içerisinde yaşayabileceklerdi. Ancak İngiltere'nin istediği gibi yerleşmeleri için onlara belli bir bölge verilmesi halinde zaten bir devletin desteği olmadan yaşayabilmeleri mümkün görünmemekteydi. Nasturiler İngilizlere güvenerek Türk hükümetinin eski yurtlarına dönme teklifini kabul etmemişler ve bir kez daha İngiltere'nin çıkarları için kendilerini kullanmasına zemin hazırlamışlardır.

Cemiyet-i Akvam Meclisi komisyonun kararını görüşmeye başladığında Türkiye bu karara sert tepki vermiştir ${ }^{90}$. Türkiye'nin tepkilerine karşı tekrar taarruza geçen İngiltere bu defa da Türkiye'nin Hakkari civarındaki Nasturileri baskı altında tuttuğunu iddia etmiştir ${ }^{91}$. Hatta İngiltere iddialarında daha da ileri giderek Brüksel Hattı'nın güneyindeki 6000 Nasturi'nin Goyan'dan Başkale'ye tehcir edildiğini ve pek çok Nasturi'nin

arasında taksimine karar verirse Küçük Zap çizgisinin sınır olabileceğini de eklemiştir. Kürkçüoğlu, a.g.e., s. 295-296

${ }^{86}$ Hakimiyet-i Milliye, 21 Nisan 1925.

${ }^{87}$ Anzerlioğlu, a.g.e., s. 156.

${ }^{88}$ Ayın Tarihi, C. V, S. 17, s. 444.

89 Öke, a.g.e., s. 165.

${ }^{90}$ Kürkçüoğlu, a.g.e., s. 296-297.

${ }^{91}$ Öke, a.g.e., s. 171. 
hayatını kaybettiğini ileri sürmüş, bölgeye bir araştırma heyetinin gönderilmesi ve Nasturilerin Irak mandası altına yerleştirilmelerini istemiştir $^{92}$. Türkiye'nin ise bu iddiaya cevabı 16 Eylül 1925 'te gelmiş ve İngiltere'nin bütün iddiaları reddedilerek Nasturilerin son günlerde meydana gelen huzursuzlukları İngiltere'nin teşviki ile yaptıkları belirtilmiş̧ir. Ayrıca tüm bu iddiaların Türkiye aleyhine bir kamuoyu yaratma çabasından ileri geldiği de ifade edilmiştir ${ }^{93}$. Türkiye'nin komisyon raporuna karşı çıkması üzerine Cemiyet-i Akvam Meclisi 19 Eylül 1925'te Milletlerarası Daimi Adalet Divanı'nın istişari mütalaasına başvurulmasını kararlaştırmıştır.

Bu arada İngiltere'nin isteği ile söz konusu iddiaların incelenmesi için Estonya Ordusu eski Genelkurmay Başkanı General Laidoner başkanlığında bir komisyon çalışmalara başlamıştır. 16 Kasım'da Musul'dan yazan Laidoner, Hıristiyanların Türkler tarafından tehcir edildiği iddialarını kabul etmekle kalmamış aynı zamanda Türkiye'nin sınırdaki statükoyu bozmak suretiyle Brüksel Hattı'nın güneyine sarktı̆̆g ithamlarını da onaylamıştır ${ }^{94}$.

Nasturilerin durumuna ilişkin açıklama zaten 24 Ekim'de Ankara tarafından yapılmıştı. Ankara, Siah ve Ziyaret köyleri sakinlerinin ihtilaflı araziye göç ettiklerini yalanlamıyordu. Ancak bu köylerin halkı dini liderlerinin de dâhil olduğu bir ihanet şebekesi oluşturmuşlardı. Nasturilerin çoğu devletlerine bağlılıklarını ifade etmişler ve bu müdahaleye engel olunmasını istemişlerdi. Hatta bazıları bizzat hükümete başvurarak bu hattan içerilere alınmalarını istemişlerdi. Yine de Ankara İngiltere'nin iddia ettiği gibi Gellikoyun/Gıllıgoyan bölgesindeki Nasturilerin yer değiştirmelerini istememiştir. Bütün bu iyi niyetlerin üzerine generalin raporu Tevfik Rüştü Bey'in ifadesiyle Ankara'da büyük bir şaşkınlık yaratmıştı ${ }^{95}$.

Mesele TBMM'nin 12 Aralık tarihli oturumunda görüşülmüş, İsmet Paşa gelişmeleri değerlendirdiği bir konuşma yaparak mezkûr heyetin Türklerin Cemiyet-i Akvam'a müracaat edip araştırılmasını istediği hususlardan birçoğunu bırakıp sadece Brüksel Hattı ve Hıristiyan tehcirini incelediğini belirtmiştir. Konuşmasında Nasturi tehciri meselesine de temas eden İsmet Paşa, İngilizlerin tahrikiyle dürüst hareket etmeyen Nasturilerin 1924 takibatı esnasında aileleriyle birlikte kısım kısım güneye gitmiş olduklarını söylemiştir ${ }^{96}$

1925 yılına gelindiğinde bir yandan Şeyh Sait isyanı diğer yandan da sınır meseleleriyle uğraşan Türk hükümetinin Nasturilerin Irak ordusu

${ }^{92}$ Öke, a.g.e., s. 172; Hakimiyet-i Milliye, 18 Eylül 1925.

${ }^{93}$ Hakimiyet-i Milliye, 18 Eylül 1925.

94 Öke, a.g.e., s. 173 .

${ }^{95}$ Mim Kemal Öke, Belgelerle Türk-İngiliz İlişkilerinde Musul ve Kürdistan Sorunu, 1918-1926, Ankara, Türk Kültürünü Araştırma Enstitüsü Yayınları, 1992, s. 162. 116.

${ }^{96}$ TBMM Zabıt Ceridesi, 2. Dönem, 23. İçtima, 1. Celse, 12. 12. 1341, C. XX, s. 111- 
içerisinde yer almalarını önlemek adına bir grup Nasturi'nin eski yerlerine dönmelerine izin verdiğine dair bilgiler de bulunmaktadır ${ }^{97}$.

İngiltere ile Türkiye arasında uzayıp giden tartışmalar olurken Adalet Divanı da 21 Kasım 1925'te şu unsurları kapsayan bir karar almıştır:

Taraflar Lozan Antlaşması'nın 3. Madde 2. Fıkrası'nı imzalamakla sorunun kesin çözümünü sağlamak yani uyuşmazlık konusu olan sınırları saptamak istemişlerdir. Dolayısıyla Cemiyet-i Akvam Meclisi'nin bu madde gereğince alacağı kararın iki taraf için de bağlayıcı olması gerekmektedir.

Meclis kararını oy birliği ile almak zorundadır. Tarafların temsilcileri oylamaya katılacak, fakat oy birliğinin saptanmasında bunların oyları göz önünde tutulmayacaktır ${ }^{98}$.

Söz konusu mütalaanın meclisçe de onaylanması ile Türkiye anlaşma hükümlerinin ihlal edildiğini öne sürerek temsilcilerini geri çekmiştir.

Gerçek şudur ki Cemiyet-i Akvam Meclisi'nin Musul'u Irak'a bırakan bu kararı, Irak ya da İngiltere'nin haklı olmasından kaynaklanmamıștır. Esasen Cemiyet Meclisi siyasi bir organdır. Bu organda alınan kararlar Milletlerarası Daimi Adalet Divanı'nın düşüncesine rağmen siyasi çıkarların etkisi altında kalmaktadır. Musul meselesi Cemiyet Meclisi'nde görüşülürken, İngiltere Cemiyet'in en nüfuzlu üyelerinden biri ve Meclis'in daimi üyesi bulunuyordu. Buna karş1lık olarak Türkiye Cemiyet-i Akvam'ın üyesi bile değildi. Meclisin Türkiye aleyhinde karar almasında bu durumun önemli bir rolü vardır ${ }^{99}$.

Türkiye'nin Musul üzerindeki İngiliz oldubittisini kabul etmesi beklenemezdi. Ancak bu tutumunda kısa süre direnebilmiştir. 5 Haziran 1926'da Türkiye, İngiltere ve Irak Hükümetleri arasında yapılan Ankara Antlaşması ile Türkiye ve Irak arasındaki sınır küçük değişiklikler yapılmasına rağmen İngiltere'nin istediği biçimde çiziliyordu. Böylece Türkiye'nin güneydoğu sınırına son şekli verilerek Misak-1 Milli'den fedakârlık etmek pahasına da olsa Türkiye'nin İngiltere ile olan son büyük anlaşmazlığı ortadan kalkıyordu ${ }^{100}$.

Nasturilere gelince, İngiltere Dışişleri Bakanı Chamberlain, kendisine yöneltilen Nasturilerin can ve mal güvenliğinin antlaşma ile teminat altına

\footnotetext{
${ }^{97}$ Anzerlioğlu, a.g.e., s. 161.

${ }^{98}$ Kürkçüoğlu, a.g.e., s. 298.

${ }^{99}$ Mehmet Gönlübol, Cem Sar, Vd., Olaylarla Türk Dış Politikası, (1919-1995), 9. Baskı, Ankara, Siyasal Kitabevi, 1996, s. 75.

${ }^{100}$ Kürkçüoğlu, a.g.e., s. 318. Antlaşmanın diğer maddeleri için Bkz. Kürkçüoğlu, a.g.e.,
} s. $318-320$. 
alınıp alınmadı̆̆ı yönündeki soruya cevaben; en iyi garantinin İngiltere ile Türkiye'nin dostluğu olduğunu söylemiştir ${ }^{101}$.

Böylece Musul meselesi ile birlikte Nasturi meselesi de kapanmış oluyordu. İngiltere, "Nasturi yurdu" manevrasında başarılı olmuştur. Nasturileri yerleştirecek bir toprak elde edememiş olmasına rağmen onları kullanarak yapmış olduğu çeşitli oyunlarla Musul meselesinin aleyhimizde çözümlenmesine olanak sağlamıştır. İngiltere, Nasturileri isyana teşvik ederek Türkiye'yi bir yandan bu konuyla meşgul ederken bir yandan da "Nasturi yurdu" projesini uygulamaya çalışmıştır. Bunu yaparken de Türk toprağı olan Hakkari'yi Nasturiler için istemiş, daha sonra da adeta taviz verir gibi Türkiye'ye bırakmıştır ${ }^{102}$.

$\mathrm{Bu}$ tarihten sonra İngiliz manda yönetimi bitinceye kadar sessiz sedasız yaşamlarını geçiren Nasturiler, İngiliz mandaterliğinden sonra Irak'ta huzursuz olmaya başlayacaklardır.

\section{Irak Yönetiminde Nasturiler}

1932 yılı başlarına kadar Irak'ta Nasturi sorunu çözümlenememiş ve aksine daha da büyüyerek devam etmiştir. 1932'de İngiltere'nin Irak'taki manda yönetimini kaldırmak istemesi Nasturileri zor durumda bırakmıştır. Nasturiler İngiltere'den bir fayda görmeyeceklerini anladıklarında Irak'la İngiltere arasındaki antlaşmayı protesto etmek için silahlı kuvvetlerini dağıtmışlardır. Bu olay İngiltere'nin sert tepkisine sebep olmuş ve Nasturi patriğine başvuran İngiltere birliklerin tekrardan kurulması için cemaatinin ikna edilmesini istemiştir. İngiltere buna karşılık Hakkari konusuna bir çözüm bulma sözü de vermiş̧tir. Nasturi Patriği Mar Şimun taburların tekrar kurulması için komutanları ikna etmeyi başarmış ancak İngiltere sözünde durmayarak Nasturilerin Hakkari'ye dönmeleri konusunda hiçbir şey yapmamışıtır.

Irak'1n Ekim 1932'de Cemiyet-i Akvam üyeliğine kabulü görüşmeleri sırasında Nasturilerin durumu da gündeme gelmiştir. İngiltere burada onların tekrar Hakkari'ye dönmelerinin en iyi çözüm olacağını belirtmiş bu mümkün olmazsa Nasturilerin Irak'ta geçici olarak ikamet edeceği vurgulanmıştır. Ancak bu görüşmeler sonucunda Nasturilerin sorunlarına tam bir yanıt bulunamamıştır. Onların Irak topraklarında parçalar halinde çeşitli bölgelere yerleştirilmelerine karar verilmiştir ki bu durum Nasturiler açısından büyük bir dezavantaj olacaktır ${ }^{103}$.

${ }^{101}$ Öke, Belgelerle..., s. 176.

${ }^{102}$ Süleyman Hayrullah Çetin, Türkiye'de Nasturi Hareketleri (1830-1926), Ankara Üniversitesi Türk İnkılap Tarihi Enstitüsü, Basılmamış Yüksek Lisans Tezi, Ankara, 1988, s. 92-93.

${ }^{103}$ K. P. Matfiyef, Asurlar ve Modern Çă̆da Asur Sorunu, Çev. Vahap Kelat, İstanbul, Kaynak Yayınları, 1996, s. 128-129. 
4 Aralık 1932 tarihinde Türkiye'nin Bağdat Büyükelçiliği’’nden alınan bir raporda Nasturilerin talepleri anlatılmaktadır. Bu rapora göre, Irak'ta bulunan bir kısım Nasturiler Cemiyeti-i Akvam'a bir mazbata vererek bir takım taleplerde bulunmuşlardır. Onların talepleri Irak'ın kuzeyinde, Musul havalisinde ve hududumuz bitişiğinde, Zaho, Dahok, Akra mıntıkalarında bir Nasturi livası tesisi, bu suretle orada bir Nasturi vatanı vücuda getirilmesi ve Irak'taki Nasturilerin oraya sevk edilerek iskân edilmesinden ibarettir.

Bu talepte bulunan Nasturiler, ruhani liderleri Mar Şimun taraftarı olan Nasturilerdir. Bunlara muhalif bir grup Nasturi bulunmakla birlikte Manda Komisyonu bu grubu nazar-1 dikkate almamıştır. Manda Komisyonu tarafından yazılan kararnamede; " $\mathrm{Bu}$ iki grup birbirlerine zlt taleplerde bulunmus iseler de toplu halde yaşamak gayesindedirler" denilerek bütün Nasturilerin bir "Milli Ocak" iddiasında müttefik oldukları hükmü çıkarılmıştır. Irak hükümeti ise Manda Komisyonu'nun Nasturi taleplerinin meclise tavsiye edilmesi kararından endişe duymakla birlikte bu kararın mecliste kabul edilmeyeceğini ümit etmekteydi.

Irak'ta teşkil edilecek Nasturi yurdu talebinin bizi ilgilendiren kısmı ise Nasturilerin kendi eski vatanları olduğunu iddia ettikleri Hakkari mıntıkasının da bu topraklara dâhil edilmesini istemeleridir ${ }^{104}$.

Görüldüğü üzere Nasturiler hiçbir vakit Hakkari'den vazgeçmemişler, her fırsatta bu mıntıkaya yerleşmek için taleplerde bulunmuşlardır.

Türkiye'nin Bağdat Büyükelçiliği'nden 11 Haziran 1933 tarihinde alınan bir diğer yazıdan anladığımıza göre; Cemiyet-i Akvam Meclisi, Nasturilerin sahipsiz bir arazide toplu halde bulundurulmayarak iskân edilmesini kararlaştırmıştır. Nasturiler ise bu iskân işinden memnun görünmemekte ve hatta Irak'tan diğer memleketlere göç etmek istediklerini söylemektedirler ${ }^{105}$.

Bu arada Cemiyet-i Akvam Meclisi'nde Nasturi taleplerini müdafaa etmek maksadıyla Cenevre'ye gitmiş olan Patrik Mar Şimun Irak'a dönerek Nasturilerin Irak'ın sadık tebaası olduklarını, Irak kanunlarına bağlı olup hükümete karşı hiçbir davaları olmadığını, Cenevre'de sadece İngilizlerin Nasturileri iğfal etmiş bulunduklarını dile getirdiğini söylemiştir ${ }^{106}$.

Irak'ta Nasturilere karşı baskılar da tüm şiddetiyle devam etmekteydi. Irak hükümetinin Nasturilerin ayrı ayrı bölgelere yerleştirilmeleri ve silahsızlandırılmalarına yönelik iskân planını kabul etmeyen Nasturilerin ülkeden göçüne imkân verildi. Bunun üzerine Temmuz 1933'te çok sayıda Nasturi ülkeyi terk ederek Suriye'ye doğru göç etmeye başladı. Sınırı

\footnotetext{
${ }^{104} B C A$, Dosya No. 436106, Fon Kodu: 30/10, Yer No. 259.741.24.

${ }^{105} B C A$, Dosya No. 436112, Fon Kodu: 30/10, Yer No. 259.741.39.

${ }^{106}$ BCA, Dosya No. 436112, Fon Kodu: 30/10, Yer No. 259.741.39.
} 
geçerek Suriye'ye gelen Nasturiler kendilerinin Irak'a gönderilmemeleri için Fransız yetkililerine başvurmuşlardır. Ancak sonuç olumsuzdur. Geri dönen Nasturiler Irak topraklarına girer girmez Iraklıların saldırılarıyla karşılaşmışlardır. Nasturiler ilk saldırıları bertaraf etmelerine rağmen kuvvetlerinin yetersizliği onları zor durumda bırakmıştır. Bu arada kitle iletişim araçlarının Nasturilerin Irak'a savaş ilan ettiği yolunda haberler yayınlamaya başlaması ile ülkede durum daha da gerginleşmiştir. Bu olaylar sırasında pek çok Nasturi hayatını kaybetmiştir.

İngiltere ise hala Nasturi davası ile ilgilendiği imajını vermek için çeşitli toplantı ve konferanslar düzenlemişti. Bu toplantılarda Nasturilerin iskânı için Türkiye ve Suriye dışında bir yer kalmadığı sonucuna varılmıştır. Ancak İngiltere, Türkiye'yi o günkü şartlarda bu işten uzak tutmayı uygun görmüştür ${ }^{107}$.

23 Ağustos 1933 tarihinde Londra Büyükelçiliği’nden alınan bilgilere göre; İngiliz gazetelerinde Nasturiler lehine ve Irak hükümeti aleyhine neşriyatta bulunulmakta ve son dönemdeki kanlı olayların sorumlularının mutlaka cezalandırılması gerektiği kamuoyunda dile getirilmektedir. Hakkari'yi Türkiye'ye bırakan Cemiyet-i Akvam kararı İngiliz gazetelerince tenkit edilmekte ve Nasturilere Suriye veya diğer bir sahada yer bulunması lüzumu teklif edilmektedir. Ayrıca gazetelerde hududu geçmeye çalışan Nasturileri silahla karşılamak için Irak hududuna Türk askeri sevk edildiği havadisi de bulunmaktadir ${ }^{108}$.

Dünya kamuoyundaki gelişmeler ve İngiltere gibi bazı devletlerin müdahaleleri Irak hükümetinin olayları durdurmasına yol açt ${ }^{109}$. Irak hükümeti Nasturi birliğini bozmak için patriklerini ve ailesini Kahire'ye sürgüne gönderdi. Sonuçta Nasturiler ne özerkliğe kavuşabildiler ne de toplu halde bir yere yerleşebildiler ${ }^{110}$. Böylece Nasturi sorunu bir çözüme kavuşturulamamış başta patrikleri olmak üzere daha sonraki tarihlerde birçoğu Amerika'ya veya başka ülkelere göç etmişlerdir. Şu söylenilebilir ki; savaş Nasturileri yurtlarından etmiştir. Yıllardır yaşamlarını sürdürdükleri evlerinde güven içinde bulunurlarken, kendilerine vaatlerde bulunan devletlere güvenerek savaşmışlar ve ortada bırakılmışlardır ${ }^{111}$.

\section{SONUC}

Avrupalı büyük güçlerin Osmanlı Devleti'ndeki emperyalist emellerini sürdürebilmek amacıyla yürüttükleri diplomasi içerisinde, devleti

${ }^{107}$ Matfiyef, a.g.e., s. 139-143.

${ }^{108}$ BCA, Dosya No. 436128, Fon Kodu: 30/10, Yer No. 259.742.3.

${ }^{109}$ Olaylarda 5 ila 6 bin Nasturi'nin öldürüldüğüne dair bir bilgi bulunmaktadır. Matfiyef, a.g.e., s. 145.

${ }^{110}$ Matfiyef, a.g.e., s. 146.

${ }^{111}$ Süryanilerin Acl Sonu, Çev. Şükran Yurdagül, İsveç, Nsibin Yayınevi, 1991 s. 93. 
parçalamaya yönelik faaliyetlerinde Osmanlı Devleti'nin özellikle doğu vilayetlerinde yaşayan Hristiyanların ve bu bağlamda Nasturilerin ayrı bir yeri bulunmaktadır. Avrupalı devletlerin bu diploması içerisinde en büyük gayeleri Osmanlı Devleti topraklarında yaşayan gayr-i Müslimlere toprak vaat ederek onların devlete karşı ayaklanmasını sağlamaktır.

Nasturiler de Birinci Dünya Savaşı başlarında Rusya, 1917'den sonra da İngiltere'nin politikalarının bir yönünü oluşturmuştur. Birinci Dünya Savaşı'nda Osmanlı Devleti'ne karşı savaş açan Nasturiler, savaş sonrasında verilen sözlerin tutulmaması nedeniyle yalnız kalmışlardır. Milli Mücadele döneminde de İngilizlerle işbirliği içinde hareket eden Nasturiler Hakkari ve çevresinde faaliyetlerde bulunmuşlardır. İngiltere, kendine bağlı tampon bölgeler oluşturmak maksadı ile Nasturilerle ilgilenmiştir.

Gerek Lozan Konferansı gerekse Musul meselesi görüşmelerinde Nasturi kozunu kullanmaya çalışan İngiltere, her ne kadar istediği "tampon devletin" kurulmasını sağlayamadıysa da Türkiye'nin sıkıntılı günler yaşamasına neden olmuştur. Nasturiler ise verilen her vaade inanarak adeta İngiltere'nin kuklası haline gelmişler ancak her seferinde kaderleriyle baş başa bırakılmışlar ve toplu halde yaşama isteklerini gerçekleştirememişlerdir.

\section{KAYNAKÇA}

\section{Arşiv Belgeleri}

Başbakanlık Cumhuriyet Arşivi:

Dosya No. 436112, Fon Kodu: 30/10, Yer No. 259.741.39.

Dosya No. 436128, Fon Kodu: 30/10, Yer No. 259.742.3.

Dosya No. 436106, Fon Kodu: 30/10, Yer No. 259.741.54.

Fon Kodu: 30/18.01.01, Yer No. 10.32.1.

\section{Resmi Yayınlar}

Ayın Tarihi, C. V, S. 17.

TBMM Zabıt Ceridesi, 2. Dönem, 1. İçtima, 1. Celse, 18.10.1340, C. IX.

TBMM Zabıt Ceridesi, 2. Dönem, 23. İçtima, 1. Celse, 12. 12. 1341, C. XX.

\section{Süreli Yayınlar}

Aksiyon, 2-8 Mart 2002.

Cumhuriyet, 10 Haziran 1924, 19 Eylül 1924.

Hakimiyet-i Milliye, 13 Ağustos 1924, 9 Teşrini Evvel 1924, 21 Nisan 1925, 18 Eylül 1925. 
İkdam, 21 Eylül 1924.

İleri, 9 Şubat 1923.

Yeni Gün, 5 Şubat 1923.

\section{Araştırma Eserleri}

Akın, Veysi; "Lozan Barış Antlaşması (24 Temmuz 1923)", Türkler, C. XVI, Ankara, Yeni Türkiye Yayınları, 2002, s. 306-318.

Albayrak, Kadir; Keldaniler ve Nasturiler, Ankara, Vadi Yayınları, 1997.

-; “Günümüzde Türkiye'deki Keldani Kilisesi”, Dinler Tarihi Araștırmaları III, Hıristiyanlık Dünü, Bugünü ve Geleceği, Sempozyum, 9-10 Haziran 2001, Ankara, Dinler Tarihi Derneği Yayınları, 2002.

Anzerlioğlu, Yonca; Nasturîler, Ankara, Tamga Yayıncılık, 2000.

; "XIX. Yy. ve Sonrasında Nasturi Hıristiyanlarının Faaliyetleri”, Türk Yurdu, C. XVIII, S. 134, Ekim 1998, s. 178-187.

Bayburt, Deniz; Türk Tarihi'nde Süryaniler(1880-1938), Basılmamış Doktora Tezi, Gazi Üniversitesi Sosyal Bilimler Enstitüsü, Ankara, 2009.

Bulut, Faik; Kürdistan'da Etnik Çatışmalar Dar Üçgende Üç İsyan, 2. Baskı, İstanbul, Evrensel Basım Yayın, 2005.

Çelik, Mehmet; Süryani Tarihi (I), Ankara, Ayraç Yayınevi, 1996.

Çetin, Süleyman Hayrullah; Türkiye'de Nasturi Hareketleri (1830-1926), Ankara Üniversitesi Türk İnkılap Tarihi Enstitüsü, Basılmamış Yüksek Lisans Tezi, Ankara, 1988.

Durak, Nihat; "Süryani Ortodoks Kilisesi", Süryaniler ve Süryanilik, Haz. Ahmet Taş̆̆ın, Eyyüp Tanrıverdi, Canan Seyfeli, C. I, Ankara, Orient Yayınları, 2005, s. $187-210$.

Ergün, Ömer; "Lozan'daki Azınlık Anlayışı ve Süryaniler”, Süryaniler ve Süryanilik, Haz. Ahmet Taşğın, Eyyüp Tanrıverdi, Canan Seyfeli, C. II, Ankara, Orient Yayınları, 2005, s. 239-256.

Gönlübol, Mehmet, Sar, Cem Vd.; Olaylarla Türk Dış Politikası, (1919-1995), 9. Bask1, Ankara, Siyasal Kitabevi, 1996.

Günel, Aziz; Türk Süryaniler Tarihi, Diyarbakır, Oya Matbaası, 1970.

Hall1, Reşat; Türkiye Cumhuriyetinde Ayaklanmalar (1924-1938), Ankara, Genelkurmay Basımevi, 1972.

Kaptan, Eyüp; Lozan Konferansinda Azınlıklar Sorunu, İstanbul, Harp Akademileri Basımevi, 2002. 
Karacan, Ali Naci; Lozan, y.y., Milliyet Yayınları, 1971.

Kaşgarlı, Mehlika Aktok; Mardin Yöresi Halkından Türko-Semitler, Kayseri, Erciyes Üniversitesi Yayınları, 1991.

Kaymaz, İhsan Şerif; Musul Sorunu Petrol ve Kürt Sorunları ile Bağlantılı Tarihsel ve Siyasal Bir Ínceleme, İstanbul, Otopsi Yayınları, 2003.

Kodal, Tahir; Paylaşılamayan Toprak Türk Basınına Göre Musul Meselesi (19231926), İstanbul, Yeditepe, 2005.

Kürkçüoğlu, Ömer; Türk-İngiliz İlişkileri (1919-1926), Ankara, AÜSBF Yayınları, 1978.

Kürşad, Cengiz; "Cumhuriyetimizin Korunması (II) Nasturi İsyanları”, Belgelerle Türk Tarihi Dergisi, S. 41, Temmuz 1988, s. 26-30.

Lozan Telgrafları, Türk Diplomatik Belgelerinde Lozan Barış Konferansı, C. I, Haz. Bilal N. Şimşir, Ankara, Türk Tarih Kurumu Basımevi, 1990.

Matfiyef, K. P.; Asurlar ve Modern Çă̆da Asur Sorunu, Çev. Vahap Kelat, İstanbul, Kaynak Yayınları, 1996.

Meray, Seha; Lozan Barış Konferansı Tutanaklar Belgeler, Takım 1, C. I, Kitap 1-2, Ankara, Ankara Üniversitesi Siyasal Bilgiler Fakültesi Yayınları, 1970.

Milletler Cemiyeti Belgelerinden Musul Kerkük Sorunu ve Kürdistan'ın Paylaşımı, Milletler Cemiyeti Tarafından 30 Eylül 1924 Tarihinde Oluşturulan Komisyonun Raporu, 2. Baskı, İstanbul, Med Yayıncılık, 1991.

Nur, Rıza, Grew, C. Joseph; Lozan Barış Konferansının Perde Arkası, İstanbul, Örgün Yayınevi, 2003.

Nur, Rıza; Hayat ve Hatıratım, C. III, Altındağ, Y.y., 1968.

Oran, Baskın; Türkiye'de Azınlıklar Kavramlar, Teori, Lozan, İç Mevzuat, İçtihat, Uygulama, 2. Baskı, İstanbul, İletişim Yayınları, 2005.

--------; “Lozan'da Azınlıkların Korunması”, Toplumsal Tarih, S. 115, Temmuz 2003, s. 72-77.

Öke, Mim Kemal; Musul Meselesi Kronolojisi (1918-1926), İstanbul, Türk Dünyas1 Araştırmaları Vakfı, 1987.

---------; Belgelerle Türk-İngiliz İlişkilerinde Musul ve Kürdistan Sorunu, 19181926, Ankara, Türk Kültürünü Araştırma Enstitüsü Yayınları, 1992.

Öksüz, Hikmet; “Lozan'da Azınlıklar Meselesi”, Türk Yurdu, Kasım 1987, s. 87-98.

Özcoşar, İbrahim; Bir Yüzyıl Bir Sancak Bir Cemaat,19. Yüzyılda Mardin Süryanileri, İstanbul, Beyan Yayınları, 2008. 
Özdemir, Bülent; Süryanilerin Dünü Bugünü, I. Dünya Savaşı'nda Süryaniler, Ankara, Türk Tarih Kurumu Yayınları, 2008.

Öztemir, B.Murat; Yezidiler ve Süryaniler, İstanbul, Ekin Yayınları, 1988.

Sertoğlu, Mithat; Süryani Türklerinin Siyasi ve İçtimai Tarihi, İstanbul, Baha Matbaas1, 1974.

Sonyel, Salahi R.; The Assyrians of Turkey Victims of Power Policy, Ankara, Türk Tarih Kurumu Basımevi, 2001.

Süryanilerin Acı Sonu, Çev. Şükran Yurdagül, İsveç, Nsibin Yayınevi, 1991.

Şadillili, Vedat; Türkiye’de Kürtçülük Hareketleri ve İsyanlar, C. I, Ankara, Kon Yayınları, 1980.

Turan, Osman; Türk Cihan Hakimiyeti Mefkuresi Tarihi, C.I, İstanbul, Turan Neşriyat, 1969.

Türkiye Dış Politikasında 50 Yıl Lozan (1922-1923), Ankara, Dışişleri Bakanlığ1 Yayınları, 1973.

Üçüncü Ordu Bölgesinde Çıkan Ayaklanmalar ve Ayaklanmaların Bastırllması, Haz. Kemal Yilmaz, Ankara, 1991.

Yakın Dŏ̆u Meseleleriyle İlgili Lozan Barış Konferansı Tutanakları, 21 Kasım 1922-23 Temmuz 1923, Birinci Takım, C. I, 1. Kitap, Der. Ahmet Yavuz, Ankara, Dışişleri Bakanlığı Yayınları, 1968.

Yaşayan Lozan, Ed. Çağrı Erhan, Ankara, Kültür ve Turizm Bakanlığı Yayınları, 2003. 